\title{
Categorias funcionais e conhecimento enciclopédico ou sintaxe e significado no domínio verbal: noções aspectuais e expressão da causatividade em Ticuna*
}

Functional categories and encyclopedic knowledge or syntax and meaning in the verbal domain: aspectual notions and expression of the causative in Ticuna

\author{
Marília Facó Soares \\ Museu Nacional / UFRJ - CNPq
}

\begin{abstract}
Closely focusing on the verbal domain and functional categories here proposed, the article has the following goals: further analyze the aspects of verbal morphology of Ticuna - a tonal language, genetically isolated, and spoken in the Amazon; prove how certain aspects of meaning are determined by the syntax; and determine which proposals, among those formulated for functional categories in the verbal domain, are supported by the facts of the language. The study regards certain aspectual verb suffixes in Ticuna and the expression of the causative in this language. To achieve its objectives, the article thematically outlines the theoretical course of the functional category light verb or $\mathrm{v}$, considering implications and consequences in relation to the points which became part of its characterization. The conclusions which were reached reaffirm that aspects of meaning determined by the syntax exclude the external agent and indicate that, with respect to the causative, the type of complement selected by it is essential for the construction of an idiomatic expression. The study supports the verbalizing aspect of the $\mathrm{v}$, the dissociation between the properties of transitivity and the semantic properties of this
\end{abstract}


category (ARAD, 1999) - essential for the treatment of aspectual suffixes in the language. Regarding the causative, the fragmentation of the $\mathrm{v}$ into different types requires, however, that the possibility of formal separation between Voice and Cause be taken into consideration (PYLKKÄNEN, 2002).

\section{Keywords}

Syntax, Light verb, Aspect, Cause, Indigenous languages, Ticuna (Tikuna)

\section{Resumo}

Focalizando detidamente o domínio verbal e as categorias funcionais aí postuladas, este artigo possui os seguintes objetivos: aprofundar o exame de aspectos da morfologia verbal do Ticuna - língua tonal, geneticamente isolada e falada na Amazônia; comprovar o quanto certos aspectos do significado são aí determinados pela sintaxe; e verificar quais propostas, entre aquelas formuladas para categorias funcionais no domínio verbal, se encontram apoiadas pelos fatos da língua estudada. O exame efetuado se dá em relação a determinados sufixos aspectuais abrigados no verbo Ticuna e em relação à expressão da causatividade nessa língua. Para alcançar seus objetivos, o artigo retraça tematicamente o percurso teórico da categoria funcional pequeno verbo ou v-zinho, considerando desdobramentos e consequências com relação aos pontos que se tornaram parte de sua caracterização. As conclusões alcançadas reafirmam que os aspectos do significado determinados pela sintaxe excluem o agente externo e indicam que, no que diz respeito ao causativo, o tipo de complemento selecionado por esse é fundamental para a constituição de uma expressão idiomática. A análise realizada apoia o caráter verbalizador de $v$-zinho, a dissociação entre as propriedades da transitividade e as propriedades semânticas dessa categoria (ARAD, 1999) - essencial para o tratamento de sufixos aspectuais na língua estudada. No âmbito da causatividade, a fragmentação de v-zinho em diferentes tipos, necessita, porém, levar em consideração a possibilidade da separação formal entre Voz e Causa (PYLKKÄNEN, 2002).

\section{Palavras-chave}

Sintaxe, v-zinho, Aspecto, Causa, Línguas indígenas, Ticuna (Tikuna) 


\section{Introdução}

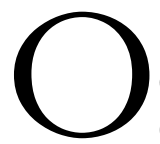

s significados especiais constituem um terreno de interface e, naquilo que diz respeito à contribuição da gramática para o seu estabelecimento, investigações sintáticas no âmbito de teorias sobre arquitetura de gramática têm demonstrado que há uma relação entre determinado domínio de localidade - por sua vez, vinculado a um tipo de categoria funcional - e a constituição desses significados. A orientação da abordagem de significados especiais a partir da definição sintática de domínios de localidade é uma posição teórica encontrada em Marantz (1997).Em conformidade com essa posição, significados especiais presentes em expressões idiomáticas e também em raízes são encontrados no contexto sintático de outros elementos que estão no interior de um domínio de localidade, na medida em que tanto expressões idiomáticas quanto raízes são definidas como elementos cujos significados não são completamente determinados por seus traços gramaticais. Em Soares (2001, p. 53-55), consideramos essa visão de Marantz como pertinente para nossos objetivos de pesquisa, ao focalizar o estudo do léxico e sua relação com as interfaces. Em Soares (2008), ao nos voltarmos para questões de tradução cultural e para expressões idiomáticas em Ticuna (língua tonal, geneticamente isolada e falada na Amazônia), focalizamos noções aspectuais nessa língua e consideramos suas possibilidades de tratamento formal. ${ }^{1}$ Encontramos exemplos da existência, na sintaxe da língua Ticuna, de conteúdo semântico na categoria funcional pequeno verbo ou $v$-zinho e discriminamos entre noções aspectuais localizáveis no âmbito dessa categoria e aquelas vinculáveis a uma projeção aspectual propriamente dita em Ticuna. ${ }^{2}$.No presente trabalho, voltamo-nos para determinados sufixos aspectuais abrigados no verbo Ticuna e para a expressão da causatividade nessa língua, também manifesta por meio de um sufixo. Ao olharmos para esses sufixos - com a permanente indagação sobre onde estão e o que fazem -, retomamos detidamente a categoria funcional pequeno verbo ou v-zinho. Na seção 2, retraçamos o percurso dessa categoria, além dos 
desdobramentos e consequências de propostas que a levaram em consideração ou que, considerando-a, tentaram a sua cisão. Sempre tendo as expressões idiomáticas em seu horizonte, a seção 2 recupera os momentos iniciais da constituição de $v$-zinho (que vão do problema dos predicados de três lugares à formação de predicados complexos) e, na sequência, aborda o papel categorizador de determinados núcleos, aí incluído o próprio $v$-zinho. Também coloca em cena a tese de que há uma sintaxe aplicada a entradas lexicais individuais que, por sua vez, acentua esse papel categorizador e inspira trabalhos na linha da Morfologia Distribuída - trabalhos esses que estabelecem uma relação entre configurações nas quais se encontra $v$-zinho, a possibilidade de dissociação entre propriedades desse último e a existência de expressões idiomáticas nas línguas naturais: Harley (1995, 2002, 2006), Pylkkänen (2002), Marantz (1997), Arad (1999). Na seção 3, com base nas configurações sintáticas e propostas apresentadas em 2, exploramos o domínio de localidade de v, através de uma análise formal dos sufixos de aspecto e causa em Ticuna. E, na seção 4, tratamos das fronteiras para a constituição de expressões idiomáticas nessa língua a partir dos sufixos mencionados, focalizamos expectativas e extraímos conclusões em termos daquilo que são nossos objetivos.

\section{A categoria funcional pequeno verbo ou v-zinho: percurso, desdobramentos e consequências}

\subsection{Da representação de predicados de três lugares à explicação para a constituição de expressões idiomáticas}

O pequeno verbo ou $v$-zinho é um núcleo/ uma categoria funcional - isto é, uma categoria não lexical que aloja traços propriamente gramaticais. Representada por um pequeno $v$ em uma configuração hierárquica, essa categoria despontou, na teoria gerativa, por meio da noção de VP shell - $a$ "concha" sintagma verbal - que constituiu um caminho, em determinado momento da teoria gerativa, para se lidar com predicados de três lugares, entre os quais estão construções bitransitivas, ${ }^{3}$ isto é, construções que apresentam dois complementos internos. ${ }^{4}$ Como possibilidades exploradas no tratamento, por exemplo, da bitransitividade, estiveram as representações em (1) e (2), que, mostradas a seguir, estariam na base da análise de sentenças como Pedro deu um livro a José ou Maria entregou uma carta a Pedro, que apresentam, 
respectivamente, um argumento externo (x) (Pedro, Maria), um tema (y) (um livro, uma carta) e um constituinte com papel temático de meta/ recipiente $^{5}$ (z) ( a José, a Pedro):

(1)
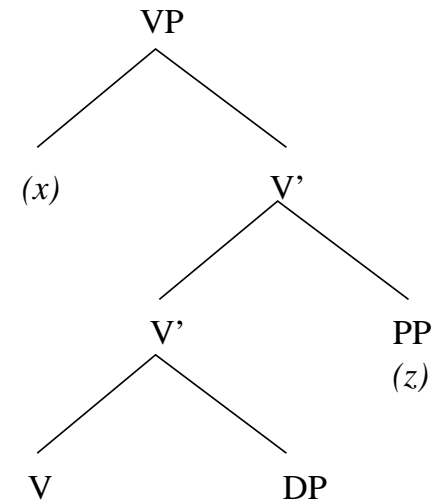

(y)

Possibilidade de representação da bitransitividade: um único VP e argumentos internos gerados nas projeções mais baixas de $\mathrm{V}$

(2)

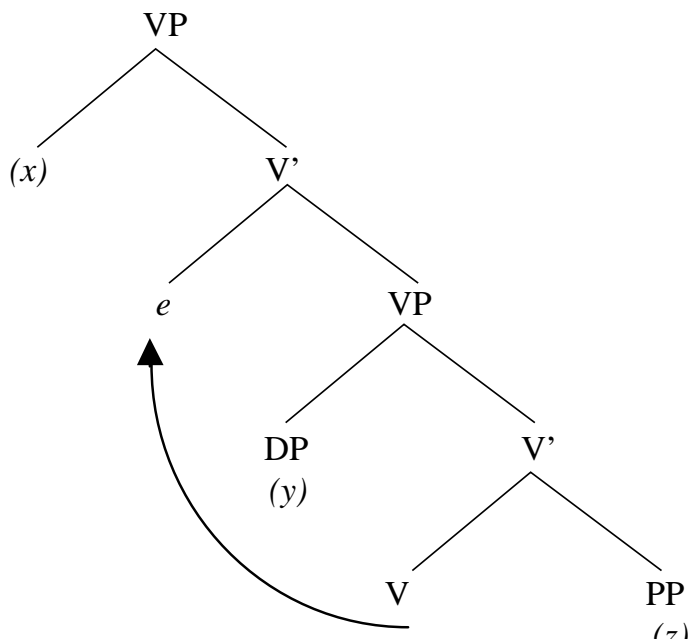

(z)

Possibilidade de representação da bitransitividade: duas "conchas” VP, núcleo vazio no VP mais alto e geração dos argumentos internos no VP mais baixo (posições envolvidas: especificador e complemento) 
Em (1), o argumento externo ( $x$ ) é gerado no especificador de VP, em conformidade com a conhecida hipótese do sujeito interno ao predicado, ${ }^{6}$ e os argumentos internos têm a sua geração efetuada nas projeções mais baixas de V no interior do que é um único VP. Nessa representação, o sintagma determinante (DP) com papel de tema (y) possui uma relação mais próxima com o verbo (V), e a projeção daí resultante (V') junta-se ao constituinte que, com papel temático de meta/ recipiente (z), encontra-se abrigado sob PP, o sintagma preposicional, e compõe com esse último o que também é um V'. Em (2), o argumento externo $(x)$ também é gerado no especificador de VP, mas, diferentemente de (1), a geração se dá no que é o VP mais alto, já que a proposta contida em (2) é a da existência de duas “conchas” VP. No interior do VP mais baixo, o posicionamento dos argumentos internos é diferente daquele visto em (1): em (2), o sintagma determinante que recebe o papel de tema ( $y$ ) é gerado como especificador do VP mais baixo, enquanto o constituinte com papel de meta (z) é que possui uma relação mais próxima com o verbo (V) no interior desse mesmo VP. Além disso, a “concha” VP mais baixa, mais interna, tem por núcleo o verbo (V), enquanto a “concha” VP mais alta, mais externa, possui um núcleo vazio, desprovido de traços $\left(e^{7}\right)$. Sem colocar qualquer exigência em termos de grade temática, esse núcleo vazio é, em (2), um guardador de lugar para o verbo que, movendo-se de sua posição original, atribui papel temático externo ${ }^{8}$ ao especificador da “concha” VP mais alta. Além disso, em (2), como [V PP] é um constituinte, tem-se a explicação para o fato de que expressões idiomáticas podem ser formadas com um verbo e um sintagma preposicionado sem que um objeto direto delas faça parte (por exemplo, em “jogar X aos leões” "jogar às traças”, “mandar à merda”, etc. no português do Brasil).E quanto aos casos em que a expressão idiomática é constituída por verbo e objeto direto (como mandar bala/ chumbo, rasgar seda, bater as botas, soltar a franga, juntar os trapos, etc., também no português do Brasil), esses poderiam continuar a ser explicados por meio da mesma configuração em (2): o verbo, ao mover-se de sua posição original para a posição onde está $e$, formaria, em um determinado ponto da derivação, um constituinte sintático com o VP, que inclui o objeto direto - o que explicaria não só o caso de expressões idiomáticas constituídas de verbo e objeto direto, mas também aquelas compostas por verbo, objeto direto e objeto indireto (como dar nozes a quem não tem dentes, entregar o ouro ao bandido, juntar o útil ao agradável, existentes igualmente no português do Brasil). 
À parte a questão do argumento externo, a representação em (1) corresponderia, grosso modo, ao que se tem em Marantz (1984) para a estrutura de base da construção com complemento duplo em, por exemplo, uma língua como o inglês, desde que essa construção não constitua um dative shift. ${ }^{9}$ Já a representação em (2) corresponde à proposta de Larson $(1988,1990)$ para esse mesmo tipo de construção e apresenta vantagens diante daquela que se vê em (1): uma delas é a já mencionada explicação para a constituição de expressões idiomáticas; a outra é que, na segunda representação, o sintagma determinante com papel de tema $(y)$ é gerado no especificador da "concha” VP mais baixa e, pode, assim, c-comandar o sintagma preposicionado com papel de meta (z) - o que torna claro por que sentenças como Paulo entregou Maria à sua própria sorte e Paulo apresentou Maria a si mesma são consideradas gramaticais por falantes nativos de português e por que sentenças como *Paulo entregou sua ${ }_{i}$ própria sorte a Maria $_{i}^{10} \mathrm{e}^{*}$ Paulo apresentou si mesma a Maria são tidas como agramaticais pelos mesmos falantes. ${ }^{11}$ As vantagens da proposta de Larson quanto à constituição de expressões idiomáticas não foram suficientes para deixá-la isenta de questionamentos, ${ }^{12}$ sobretudo porque se encontra atrelada a uma análise pela qual a construção com dative shift é vista como derivada daquela com complemento duplo, sem que sejam levadas em consideração a ausência de uma perfeita correlação e/ou existência de distinções semânticas entre ambas, algumas das quais objeto de atenção do próprio Larson. ${ }^{13}$ Anos mais tarde, em uma abordagem não lexicalista, Harley (2002, p.34) proporá - contrariamente a Larson - que as estruturas com complemento duplo e aquelas vinculadas ao dative shift (por ela chamada de estruturas com objeto duplo e relacionáveis à posse) são alternativas sintáticas resultantes de projeções que, na base, são diferentes. E decomporá os verbos de tais construções em dois núcleos funcionais - um dos quais é um $v$-zinho CAUSA que seleciona argumento externo e que tem por complemento um sintagma preposicionado. ${ }^{14}$ Anteriormente a isso, porém, surgirá uma solução para o núcleo vazio da "concha” VP mais alta da proposta de Larson $(1988,1990)$. Pontos relevantes para a abordagem do domínio verbal e a constituição de expressões idiomáticas, esse núcleo e a sua face como $v$-zinho CAUSA são focalizados, respectivamente, em 2.2 e 2.3 a seguir. 


\subsection{O pequeno verbo ( $v$-zinho) e o caminho para a categorização de determinados núcleos}

Apesar das vantagens mencionadas em 2.1 e relacionadas à constituição de expressões idiomáticas e ao c-comando do sintagma com papel de meta por parte daquele que exerce o papel de tema, desenvolvimentos ulteriores na teoria gerativa, que seguiram na direção da eliminação de núcleos completamente desprovidos de traços, ${ }^{15}$ levaram à identificação de um problema na representação mostrada em (2): a existência de um núcleo completamente vazio a partir do qual é projetada a "concha” VP mais alta.Um caminho de solução para esse problema pôde ser divisado a partir do momento em que a "concha” VP mais alta teve o seu núcleo vazio (e) substituído por um pequeno verbo ou v-zinho (v), que projeta um sintagma v-zinho (vP), tal como se vê em (3a). Elemento que pode ser fonologicamente nulo ou abertamente manifesto, ${ }^{16}$ o pequeno verbo ou v-zinho tem o seu significado dependente do seu complemento (o até então VP mais baixo, mais interno), formando com esse último um predicado complexo. Além disso, v-zinho é também visto como portando um traço verbal forte desencadeador do movimento de $\mathrm{V}$ (o chamado verbo de conteúdo), que se adjunge então ao próprio v-zinho (como mostrado em (3b)).

(3) a.

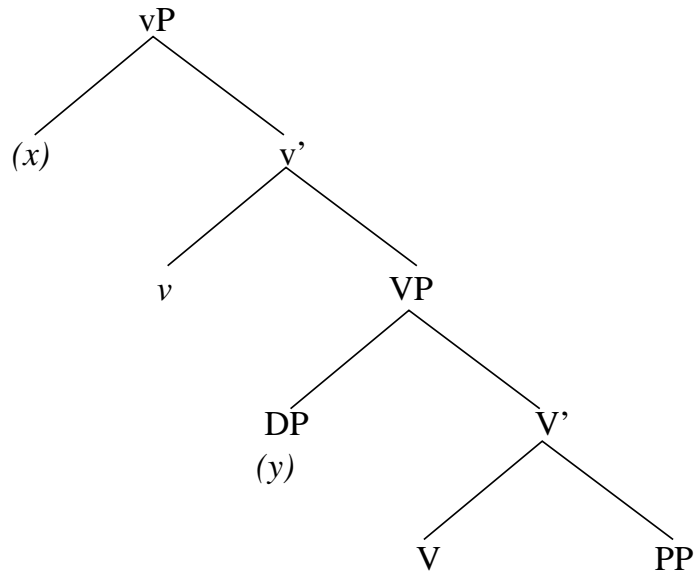

(z)

O núcleo v-zinho (v) e a projeção do sintagma v-zinho (vP) 
(3) b.

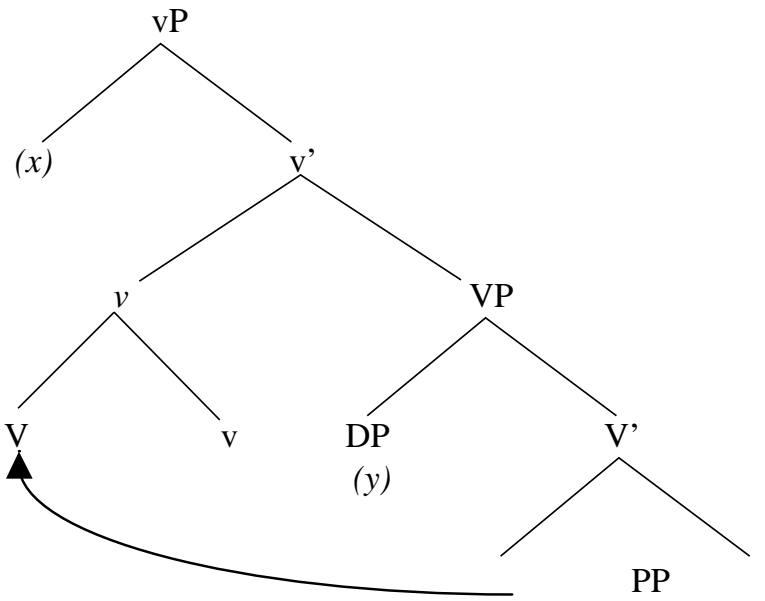

(z)

Movimento de V e adjunção a v-zinho

A introdução teórica de $v$-zinho foi avançada de forma independente em trabalhos que antecedem a sua adoção explícita por Chomsky $(1995,1998)$, estando entre esses trabalhos Hale e Keyser (1993). Se em Chomsky há um foco sobre $v$-zinho como núcleo funcional transitivo que introduz um argumento externo (sujeito) e é ainda responsável pela checagem do caso estrutural relativo ao argumento interno (objeto), outro é o foco em Hale e Keyser (1993). Nesse último trabalho, estão em primeiro plano o movimento do núcleo mais baixo ${ }^{17} \mathrm{e}$ sua adjunção ao verbo matriz. Também está aí a proposta de que todos os verbos, mesmo os inergativos (os verdadeiros verbos intransitivos) são constituídos de dois núcleos separados (V e N), tal como se vê, a título de exemplo, em (3c). Essa estrutura é a representação inicial que Hale e Keyser propõem para verbos como run e correr, existentes, respectivamente, em inglês e em português; ela mostra também a propriedade categorizadora (isto é, a propriedade verbalizadora) que o núcleo verbal assume nesta teoria, já que, combinado a algo que não é um verbo, esse núcleo leva à constituição de uma forma verbal: 
(3) c.

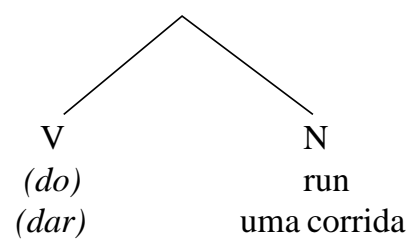

Representação de verbo inergativo nos termos de Hale and Keyser (1993)

No caso dos verbos transitivos, os dois núcleos que estão em jogo pela proposta de Hale \& Keyser (1993) são o verbo mais baixo, que introduz o que é seu argumento interno e projeta o VP, e o verbo matriz que, coincidindo com $\mathrm{o} v$, introduz o argumento externo em seu especificador e toma o VP como seu complemento, tal como, de modo muito próximo, se viu na representação em (3b). É importante ressaltar aqui que a tese central de Hale e Keyser (1993) é a de que a estrutura argumental do predicado é ela própria uma sintaxe, isto é, uma sintaxe aplicada a entradas lexicais individuais ${ }^{18}$ - o que importa na grande diferença entre ambos os autores e Chomsky: ${ }^{19}$ em Hale e Keyser, embora estruturas como (3c) estejam representadas como tal em um léxico cuja concepção não é profundamente discutida por ambos, ainda assim pode-se dizer que essas são inseridas, sob a forma como se encontram no léxico, nas representações sintáticas, estando, portanto, disponíveis para manipulação sintática “na sintaxe propriamente dita”. A tese central de Hale e Keyser (1993) acentuará o papel categorizador de determinados núcleos.E inspirará, na linha do tempo, pesquisadores identificados com a vertente da teoria gerativa conhecida como Morfologia Distribuída, ${ }^{20}$ levando-os a revisitar a proposta de Hale \& Keyser (1993) e a modificá-la ligeiramente no que toca a aspectos da representação do núcleo coincidente com o pequeno verbo ou v-zinho. É o que fazem Harley (1995, 2006) e Pylkkänen (2002), que retomam a representação das construções causativas (com morfema/verbo causativo e núcleo funcional relacionado) e aquela dos verbos intransitivos inacusativos ${ }^{21}$ (também chamados incoativos ou verbos ergativos com uso intransitivo). Ambas as construções integram a história da categoria pequeno verbo ou v-zinho, tendo sido precedentemente abordadas por Hale e Keyser (1993). A iniciativa de retomada de tais construções também se faz presente em Arad (1999), que admite a possibilidade de $v$-zinho acolher determinadas noções aspectuais. 


\subsection{Propostas: v-zinho em "diferentes sabores", seu desdobramento em categorias funcionais distintas e dissociação de suas propriedades. Possibilidades e fronteiras para a constituição de expressões idiomáticas}

Harley (1995) propôs que um $v^{\circ}$ também estava presente em construções intransitivas inacusativas, mas que esse era um $v^{\circ}$ distinto, que não selecionava argumento externo, o que diferenciaria assim essas construções daquelas que se apresentam com verbos causativos. Por sua vez, esses últimos, em razão de uma decomposição lexical que Harley firma em trabalhos posteriores, podem se fazer presentes em construções que não exibem abertamente um morfema causativo. É o caso das construções com complemento duplo e com dative shift, vistas em 2.1, que, nos termos de Harley (2002), possuem um v-zinho CAUSA cujo complemento é um sintagma preposicionado. ${ }^{22}$ Abertamente manifesto ou não, nessa ou em outras construções para as quais possa ser proposto, o morfema causativo - vinculável a um v-zinho CAUSA - se caracteriza, nos trabalhos de Harley, por selecionar um argumento externo. Mantida em Harley (2006), ${ }^{23}$ a diferença entre $o v^{\circ}$ presente em construções intransitivas inacusativas e o núcleo v das construções com verbos causativos pode ser visualizada através das representações em (4a) e (4b):

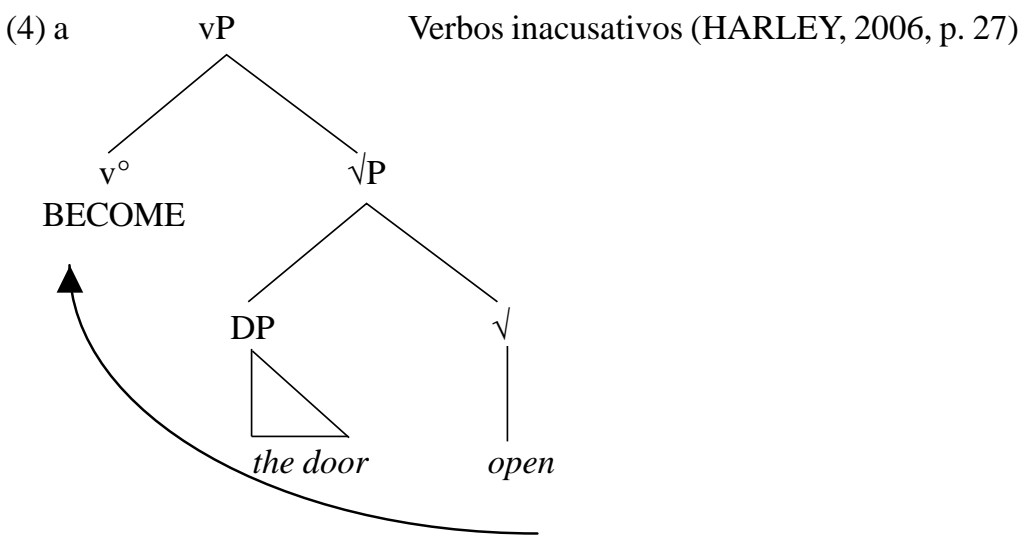


(4) $b$

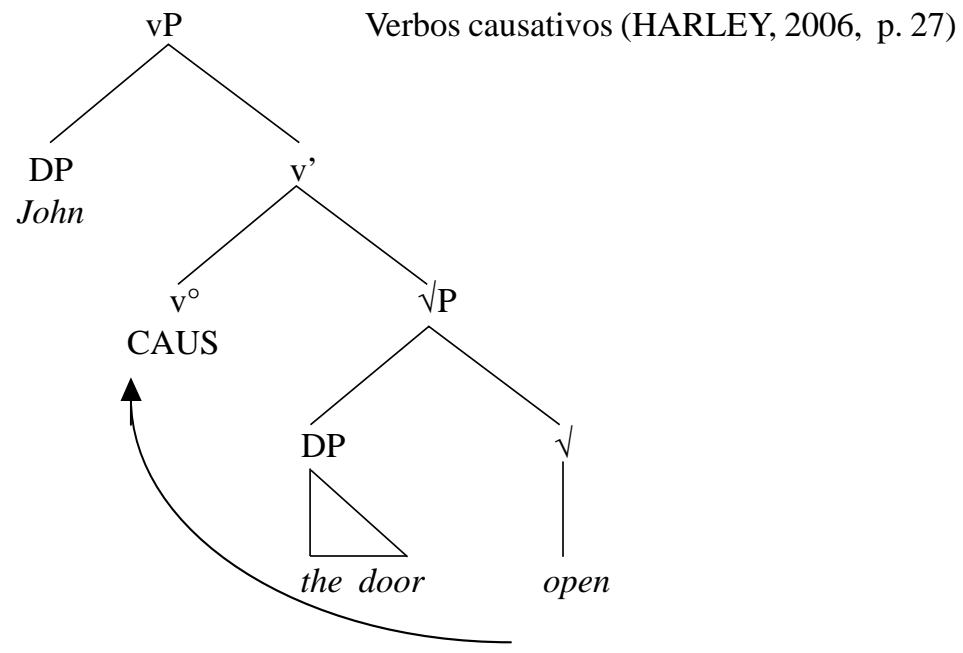

Em (4a), [BECOME the door open] ('tornar-se/ ficar a porta aberta') é a representação inicial do predicado de uma sentença como The door opens/ opened ('a porta abre/ abriu') em inglês: a categoria funcional / núcleo v toma como complemento não um VP, mas um sintagma raiz (root phrase $-\sqrt{ } P$ ), constituído, por sua vez, de uma raiz $(\sqrt{ }$ - open) e de um argumento interno (the door 'a porta'). O núcleo desse sintagma (uma raiz - $\sqrt{ }$, open) move-se, adjungindo-se ao núcleo $v$-zinho, daí resultando um núcleo complexo. Nessa representação, $v$-zinho não introduz um argumento externo, e o aparecimento de the door 'a porta' como sujeito superficial dependerá de seu movimento para fora do sintagma do pequeno verbo ou v-zinho (vP). Em (4b), está a representação inicial de uma sentença como John opens/ opened the door (João abre/ abriu a porta), também em inglês. Aí o v-zinho CAUSA introduz um argumento externo no interior do vP, diferenciando-se do $v$-zinho que não o faz. Nesse ponto, existem, a nosso ver, dois avanços. O primeiro é a proposta da existência de mais de um tipo de $v$-zinho. E o segundo, a proposta de esse núcleo também poder tomar como seu complemento um sintagma raiz. ${ }^{24}$ Essa segunda diferença é o que permite, ainda, a Harley estabelecer - em seu artigo de 2006-a diferença entre causativas lexicais e causativas sintáticas na análise que faz da construção causativa em japonês. Nessa língua, as causativas lexicais se comportam sempre como mono-oracionais, são improdutivas e podem ter interpretações idiomáticas. Para essas, Harley propõe a representação em(5a), em que há uma única “concha” 
vP e o núcleo $v$-zinho CAUSA tem como seu complemento um sintagma raiz $(\sqrt{ } \mathrm{P})$, isto é, um sintagma cujo núcleo é uma raiz. Já as chamadas causativas sintáticas do japonês (também conhecidas como produtivas) são bi-oracionais por determinados testes ${ }^{25}$ e não apresentam interpretações idiomáticas. A proposta de Harley para essas últimas está em (5b), uma representação em que o $v$-zinho CAUSA da “concha” $v P$ mais alta toma por complemento um outro vP, ou seja, um outro sintagma do pequeno verbo ou $v$-zinho, que é um complemento estruturalmente completo em termos de estrutura argumental - na realidade, seu complemento é um outro vP, com seu próprio argumento agente (argumento externo) independente. Em outros termos, vP é aí o locus das propriedades sintáticas relevantes que sugerem uma abordagem bi-oracional e não propiciadora de interpretações idiomáticas .

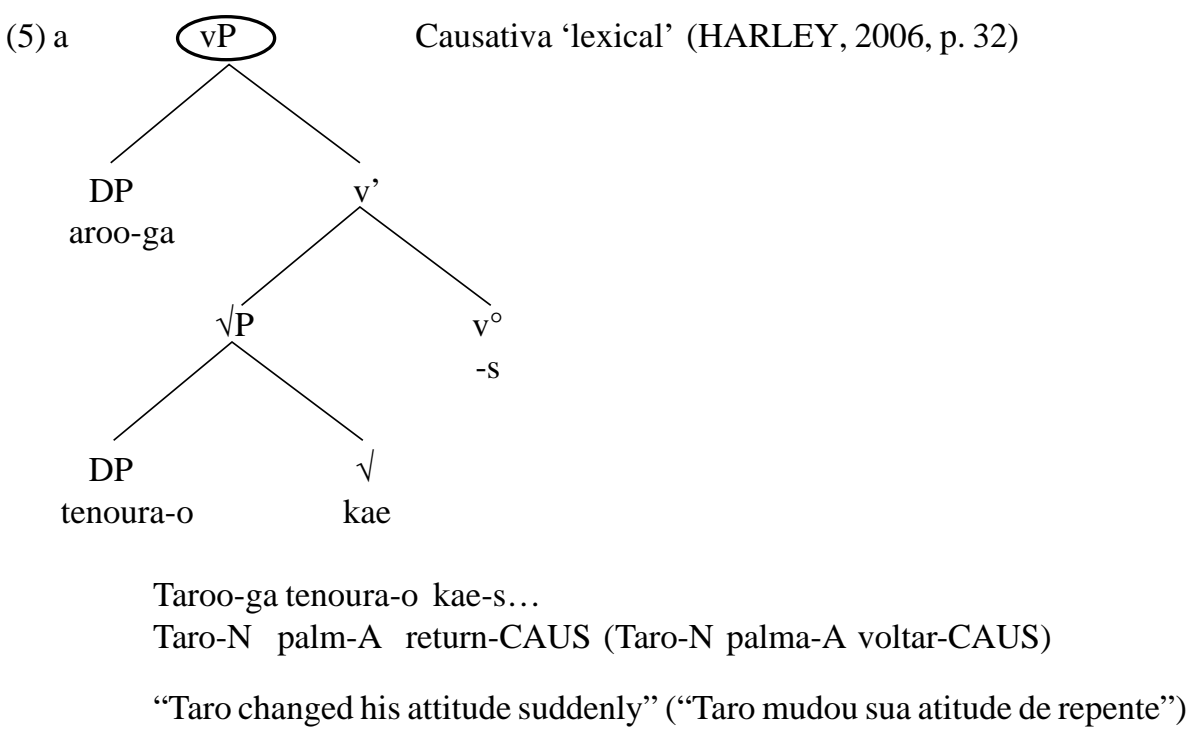


(5) $b$

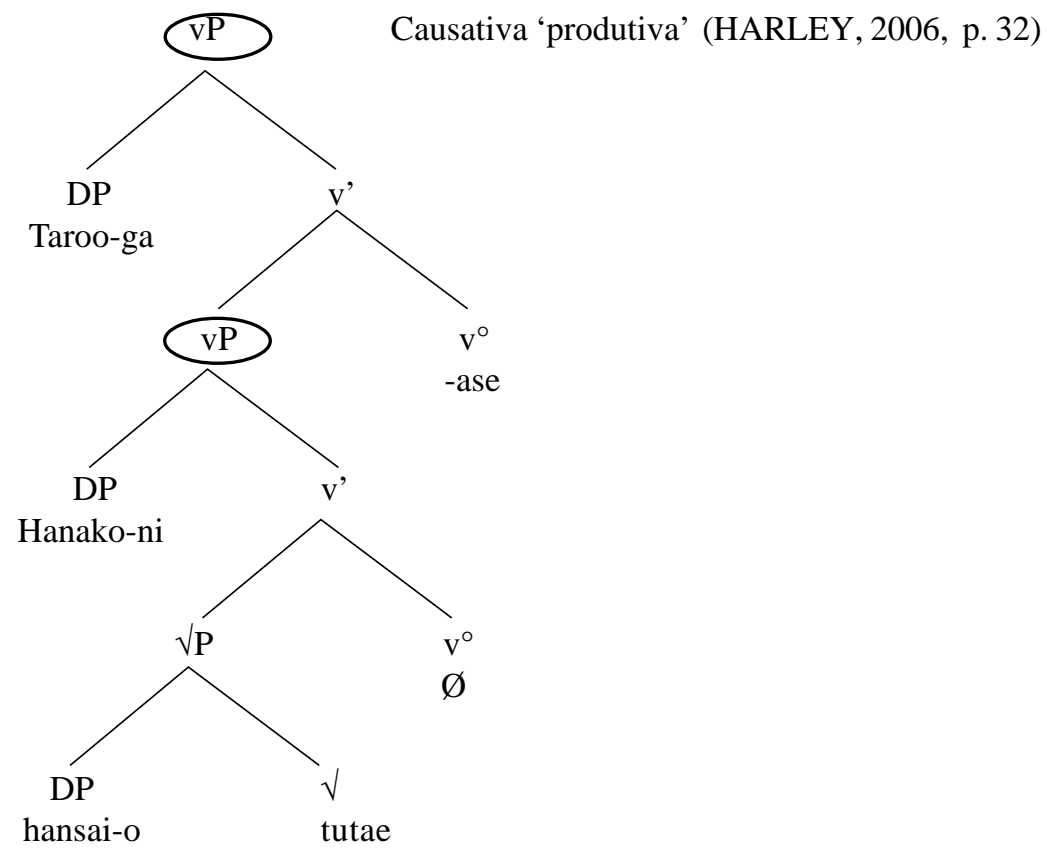

Taroo-wa Hanako-ni hanasi-o tutae-sase-ta

Taro-T Hanako-D story-A convey-CAUS-PAST

Taro-T Hanako-D história transportar,levar, transmitir-CAUS-PASS

“Taro made Hanako convey a story” ("Taro fez Hanako transmitir uma história”)

A representação em (5a) e aquela em (5b) são acompanhadas de exemplos que as sustentam. E a esse respeito é importante notar que, pela análise de Harley, tanto as chamadas causativas lexicais quanto as conhecidas como produtivas ou sintáticas apresentam um v CAUSA introdutor de agente; e que as chamadas causativas lexicais são na realidade sintáticas, já que Harley, seguindo os preceitos da Morfologia Distribuída, as resolve na sintaxe. ${ }^{26}$ Ressalte-se que é a própria representação sintática da causativa lexical (expressa em (5a)) que permite a Harley lidar formalmente com as expressões idiomáticas calcadas nesse tipo de causativa em japonês: aqui, o que possibilita a constituição de uma expressão idiomática é o tipo de complemento que $v$-zinho toma - um sintagma raiz (e não um outro vP, que é o que se dá em (5b)). 
Da mesma forma que em Harley (2006), também são importantes em Pylkkänen (2002) a seleção de um tipo de complemento por parte de um dado núcleo funcional e a possibilidade de constituição de uma expressão idiomática a partir dessa seleção. Entretanto, diferentemente de Harley, que propõe a existência de mais de um tipo de $v$-zinho (ou $v$-zinho "em mais de um sabor”), Pylkkänen trabalha, em lugar do $v$-zinho, com a proposta de dois núcleos/ categorias funcionais diferentes como parte do inventário universal de categorias funcionais, verificando suas possibilidades de projeção sintática em línguas particulares: Causa e Voz (Voice). Voz é um núcleo funcional introdutor de um argumento separado do verbo - o argumento externo - e denota uma relação temática mantida entre o argumento externo e o evento descrito pelo verbo, acrescentando a condição de que o evento possui um agente, um experienciador ou qualquer outro papel temático possível para argumentos externos. ${ }^{27}$ Cabe dizer que, nesse ponto, Pylkkänen aceita a teoria de Kratzer (1996), que não vê o argumento externo como sendo introduzido pelo verbo, porque esse não é parte do significado desse último. Na visão de Kratzer, o argumento externo é introduzido por um predicado separado chamado Voz (Voice), que se combina com o VP através de uma regra específica. ${ }^{28}$ Quanto ao núcleo funcional Causa, esse introduz apenas um evento causativo à semântica da construção. ${ }^{29}$ É voltada para a possibilidade de distinguir as projeções sintáticas de Voz e Causa que Pylkkänen busca estabelecer uma tipologia da causatividade e dar conta da variação translinguística que envolve construções causativas. Para tanto, postula dois parâmetros: o parâmetro do agrupamento ou não dos traços de Voz e Causa; e o parâmetro relacionado ao complemento selecionado por Causa.

Em conformidade com o primeiro parâmetro, as línguas que agrupam feixes de traços de Voz e Causa em um único núcleo funcional (ou seja, que são Voice-bundling Cause) apresentam, segundo Pylkkänen, a configuração vista em (6a), com construções causativas em que se tem sempre um argumento externo $(x)$ interpretado como agente, apesar de Causa ser semanticamente separado de Voz; estão nesse caso o inglês e o português. ${ }^{30}$ 
(6) a

$(x)$

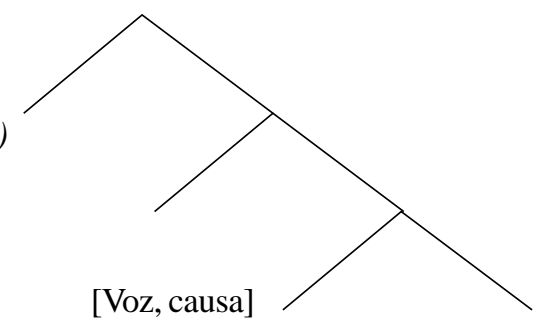

Línguas que agrupam feixes de traços de Voz e Causa (Voice-bundling Cause - PYLKKÄNEN, 2002, p. 76)

Já as línguas que não agrupam feixes de traços de Voz e Causa (Non-Voicebundling Cause) são aquelas para as quais se pode propor a representação em (6b), em que Voz e Causa constituem núcleos funcionais independentes. Exemplificadas pelo japonês e pelo finlandês, contam essas línguas com a possibilidade de exibir construções causativas sem argumento externo e, consequentemente, de não apresentar Voz em sua estrutura. Essa possibilidade equivaleria, de um lado, a uma representação assemelhada a (6b), porém sem os ramos relativos, respectivamente, à Voz e ao argumento introduzido por esse núcleo e, de outro lado, a uma interpretação que não envolve um agente. ${ }^{31}$

(6) $b$

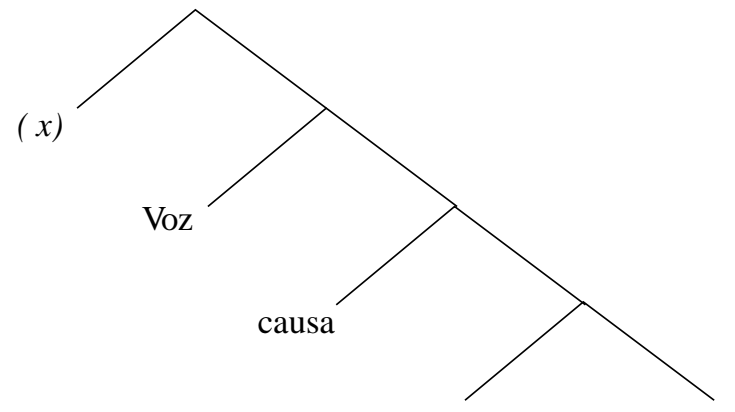

Línguas que não agrupam feixes de traços de Voz e Causa (Non-Voice-bundling Cause - Idem, ibidem)

Quanto ao segundo parâmetro, que diz respeito ao tipo de complemento que Causa pode selecionar, tem-se, na visão de Pylkkänen (2002, p.77; 94-95), as seguintes possibilidades, visualizadas em (7a), (7b) e (7c): 
(7) a

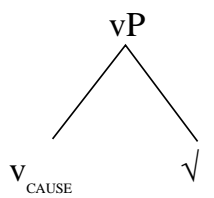

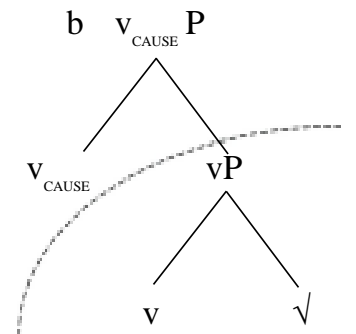

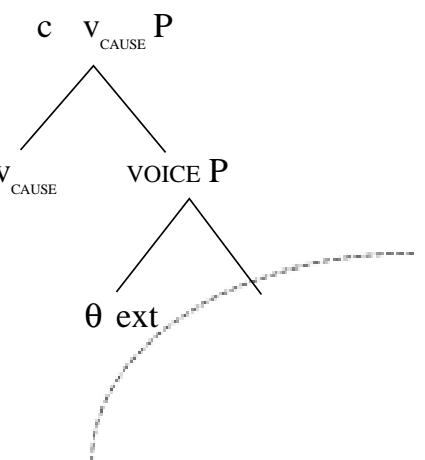

Em (7a), o complemento selecionado por Causa é a raiz, o que dá margem à constituição das chamadas causativas lexicais, propiciadoras de expressões idiomáticas. Em (7b), Causa seleciona como seu complemento o verbo (isto é, um sintagma $v$-zinho - vP), sendo que a raiz, no interior de vP, é complemento de v-zinho e é por esse verbalizada, ou seja, categorizada. E, em (7c), a seleção efetuada por Causa se dá em favor do que, no dizer de Pylkkänen, é uma nova fase, já que está presente a introdução de um argumento externo pelo núcleo Voz, no interior de um sintagma Voz (VoiceP). A previsão é de que não se deve esperar, no caso da estrutura mostrada em (7a), uma morfologia verbalizante entre o morfema causativo e a raiz, assim como a expectativa é a de que essa morfologia exista na estrutura em (7b), ${ }^{32}$ desde que não esteja relacionada à introdução de um argumento externo - o que só a estrutura em (7c) é capaz de permitir. Uma outra previsão diz respeito à modificação adverbial. Não se prevê, para (7a), ambiguidade de escopo de modificador verbal, já que, na estrutura representada, a categoria funcional Causa é selecionadora de uma raiz como seu complemento. Uma tal ambiguidade, porém, está prevista tanto para (7b) quanto para (7c), uma vez que em ambas pode haver modificação verbal do evento causado - expresso, respectivamente, pelo sintagma $v$-zinho (vP) e pelo sintagma Voz (VoiceP): em (7b) a ambiguidade de escopo não pode estar dirigida para o agente e, em (7c), um tal direcionamento é possível. ${ }^{33}$

Um outro ponto importante na proposta de Pylkkänen (2002), e que convém ressaltar, é o de que há aí a busca de uma correlação no âmbito daquilo que causativos podem selecionar nas línguas naturais. ${ }^{34} \mathrm{No}$ conjunto dos causativos selecionadores de raiz, a expectativa é a da impossibilidade - nas línguas que agrupam Voz e Causa - de se ter uma correlação perfeita entre causativização 
de inacusativos, de inergativos ou de transitivos (situação de impossibilidade verificada em inglês). Já no conjunto dos causativos que selecionam raiz e se fazem presentes em línguas que não agrupam Voz e Causa, há uma correlação entre a existência de causativos inacusativos e a possibilidade de causativização de inergativos e transitivos (situação comprovada, por exemplo, no japonês). Nas línguas que não agrupam Voz e Causa, espera-se ainda que essa mesma correlação se repita, quando o complemento selecionado pelo causativo é o verbo (isto é, um sintagma $v$-zinho - vP) ou uma nova fase, introdutora de argumento externo. Essa correlação deixa de ser perfeita em línguas que agrupam Voz e Causa e cujos causativos selecionam como seu complemento o verbo ou uma nova fase: aqui, a expectativa é a de que causativos inacusativos sejam impossíveis, havendo, porém, a possibilidade de causativizar inergativos e transitivos. Esse conjunto de expectativas pode ser explicado teoricamente: apesar das semelhanças semânticas, as construções causativas diferem sintaticamente conforme o tipo de língua. Nas línguas que agrupam Voz e Causa (caso do inglês), a relação causativa e o papel temático do argumento externo são reunidos em um único morfema e, consequentemente, em um único núcleo sintático. Como a manifestação sintática de Causa não tem aí a sua própria projeção, não só deve haver a introdução de um argumento externo, mas também fica impedido o licenciamento de um 'causado' (causee). Quanto às línguas que separam Voz e Causa, apresentando-as em projeções sintáticas próprias (caso do japonês), essas exibem, de um lado, a possibilidade da existência de construções causativas sem argumento externo e, de outro lado, a possibilidade estrutural de inserção de um 'causado' (causee). Isso explicaria as amplas possibilidades de causativização existentes em uma língua como o japonês, diante de uma causativização mais restrita em uma língua como o inglês. Ou, nas próprias palavras de Pylkkänen: “As diferentes realizações estruturais do elemento funcional CAUSA predizem que causativos inacusativos devam ser possíveis em japonês e finlandês, mas não em inglês.”35

Em se tratando da seleção de um tipo de complemento por parte de um dado núcleo funcional, é de se notar que tanto Harley (2006) quanto Pylkkänen (2002) encontraram inspiração em Marantz (1997), autor que - seguindo a trilha aberta por Hale \& Keyser (1993) - veiculou fortemente a teoria de que categorias funcionais definem a categoria sintática do que são raízes neutras em termos categoriais. Ou seja, na qualidade de possíveis elementos categorizadores de raízes neutras, em conformidade com Marantz (1997), estão as categorias funcionais 
v-zinho, $n$-zinho e $a$-zinho, que permitem a derivação, respectivamente, de verbos, nomes e adjetivos.Entre as categorias funcionais com esse papel, $v$-zinho é a que está aqui em foco. Harley (1995, 2002, 2006) a mantém, introduzindo-lhe um sabor a mais - o v-zinho CAUSA. Pylkkänen (2002) lida com outra (Causa) em seu lugar, mas de certa forma a recupera nas próprias representações em que determina os possíveis complementos de CAUSA (ver (7a), (7b), (7c)), representações essas que exibem o retorno de $v$ CAUSA - e, com ele, a volta da questão do desdobramento da categoria funcional $v$-zinho e de seu papel teórico.Esse papel já havia estado em foco em Arad (1999) e, precedentemente, em Marantz (1997). Neste último trabalho, além de integrar um conjunto de núcleos responsáveis pela já mencionada categorização sintática de raízes neutras, $v$-zinho fornece a fronteira de um domínio de localidade para a constituição de significados especiais. Isto é, conforme se vê em (8), Marantz (1997) localiza essa fronteira no próprio núcleo sintático que projeta agentes - a categoria funcional pequeno verbo ou $v$-zinho $(v):{ }^{36}$

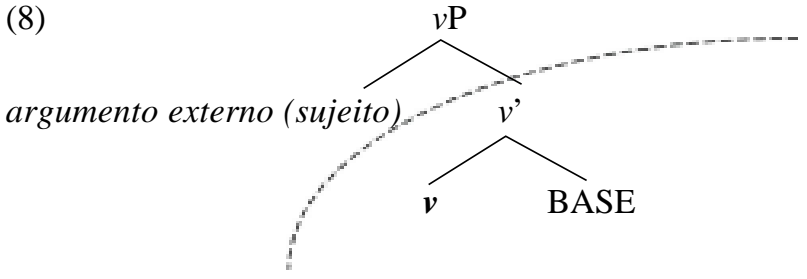

Fronteira para a constituição de significados especiais - Marantz (1997)

A consequência mais direta do estabelecimento de uma fronteira nesses termos é que nada do que estiver hierarquicamente acima da categoria funcional pequeno verbo ou $v$-zinho poderá servir como contexto para significado especial de qualquer raiz abaixo dessa categoria. Assim, expressões idiomáticas em qualquer língua nunca incluirão, por exemplo, agentes fixos, isto é, argumentos externos (sujeitos), porque esses estão acima da categoria funcional em questão, não se fazendo presentes por exigências de uma raiz, mas por imposição de um núcleo funcional (o pequeno verbo ou v-zinho). Exemplos dessa consequência podem ser vistos no português tal como falado no Brasil, em que pintar e bordar/ pintando e bordando, pintar o sete / pintando o sete, jogar merda no ventilador/jogando merda no ventilador são expressões idiomáticas, mas delas não é parte um agente, como João em João pintou e bordou, João pintou 
o sete, João jogou merda no ventilador, porque João (na qualidade de argumento externo) está impedido de ser parte de uma expressão idiomática. Na contribuição de Arad (1999), que aceita a fronteira estabelecida por Marantz (1997) para expressões idiomáticas, $v$-zinho integra uma tipologia em que propriedades assumem o primeiro plano e em que é estabelecida a dissociação entre as propriedades da transitividade e as propriedades semânticas de $v$-zinho. ${ }^{37} \mathrm{As}$ propriedades da transitividade são aquelas que (tal como já mencionamos em passagem anterior a propósito de Chomsky 1995, 1998) fizeram de $v$-zinho um núcleo funcional transitivo introdutor de argumento externo (sujeito) e responsável pela checagem do caso estrutural relativo ao argumento interno (objeto). Entre as propriedades semânticas de $v$-zinho ${ }^{38}$ apresentadas por Arad estão a agentividade, a causação e o conteúdo aspectual que, respectivamente, dão ao evento uma interpretação agentiva, ${ }^{39}$ causativa e uma interpretação em termos de processo. Dissociadas as propriedades transitivas e semânticas, o caminho seguido por Arad é o da assunção de que as línguas podem agrupar quaisquer traços relacionados a essas propriedades, formando núcleos (categorias funcionais) de diferentes tipos-ou, em outros termos, uma família de v-zinhos. Assim, desseponto de vista, há construções em que v-zinho agrupa propriedades semânticas como agentividade, processo, mas não as combina com a propriedade da transitividade, como ocorreria em determinadas construções do japonês ${ }^{40}$ e de línguas românicas ${ }^{41}$ e como ocorre nas construções passivas de um grande número de línguas. ${ }^{42}$ Da mesma forma, há construções que apresentam um tipo de $v$-zinho que compartilha a propriedade da transitividade, mas não a propriedade da agentividade, como nas construções verbais com objeto experienciador e sem agente, das quais são encontrados exemplos em várias línguas. ${ }^{43} \mathrm{E}$, no que diz respeito à combinação entre núcleos v-zinhos (entre um v-zinho mais alto e um mais baixo), essa, na contribuição deArad (1999), não se dá de maneira irrestrita, sendo levadas em consideração as propriedades que esses núcleos são capazes de manter e/ou articular. ${ }^{44}$

No percurso teórico aqui apresentado, é importante reter que a propriedade verbalizadora do núcleo coincidente com v-zinho (vista já em Hale \& Keiser, 1993) não recebeu contestações, mantendo-se presente mesmo diante de sua fragmentação em diferentes tipos (HARLEY, 1995, 2002, 2006; ARAD, 1999) e/ou em uma visão que privilegia o agrupamento de traços (ARAD, 1999; PYLKKÄNEN, 2002). Já as propriedades ligadas à transitividade - introdução de argumento externo e checagem do caso do objeto - passaram por alterações. 
A transitividade pôde ser dissociada das propriedades semânticas (ARAD, 1999); e a introdução de argumento externo e a interpretação desse argumento como agente ou foi negada para $v$-zinho como um todo (como em KRATZER, 1996, PYLKKÄNEN, 2002) ou se fez ausente apenas de modo parcial - caso das construções com verbo inacusativo, em que vP não apresenta projeção de especificador (HARLEY, 1995, 2006). No que toca ao complemento do núcleo $v$-zinho, a checagem de caso não é o que está em primeiro plano, e sim o tipo de $v$-zinho e o tipo de complemento introduzido por esse núcleo. Ou v-zinho CAUSA tem como seu complemento um sintagma da raiz $(\sqrt{ } \mathrm{P})$ e dá lugar a interpretações idiomáticas ou toma como seu complemento um outro vP, com seu próprio argumento agente (argumento externo) independente - o que impossibilita a constituição de expressões idiomáticas (HARLEY, 2006).Ou, em outros termos, porém de modo similar - substituindo $v$-zinho ou recuperando-o através de v CAUSA -, um núcleo Causa pode selecionar como seu complemento a raiz, propiciando a existência de expressões idiomáticas, ou tomar como seu complemento um sintagma v-zinho ou um sintagma Voz - situação que barra a existência de expressões idiomáticas (PYLKKÄNEN, 2002).

Levando em conta o percurso teórico acima traçado e nele as situações que podem levar a expressões idiomáticas, passemos ao domínio de localidade $v$ em Ticuna. ${ }^{45}$

\section{Explorando o domínio de localidade v: sufixos de aspecto e causa em Ticuna}

\subsection{Sufixos aspectuais}

Duas são as noções aspectuais materializadas no verbo em Ticuna por meio de formas sufixais que apresentam um possível caráter verbalizante: a de aspecto continuativo, que adiciona o elemento semântico 'ainda' e a de aspecto habitual, que descreve uma situação característica de um período extenso de tempo. ${ }^{46}$ Essas noções aspectuais são expressas, em Ticuna, respectivamente pelos morfemas - $\tilde{u}$ e -etcha.

O sufixo - $\tilde{u ̈}^{47}$ ‘continuativo' leva à interpretação de continuidade, de longa duração de um evento/ estado cujo término permanece em aberto. Vejamse os dados em (9): 
(9) a. na-pe-ü

3P-dormir-CONTINUATIVO

'ele dorme/dormiu continuamente'

b. Bucü na-pe-ü $\quad$ i napa wa menino 3P-dormir-CONTINUATIVO $\mathrm{x}$ rede LOCATIVO 'O menino dorme/dormiu na rede continuamente' 'O menino continua/ continuou a dormir'

c. na-tchibü-ü

3P-alimentar/comer-CONTINUATIVO

'continua/continuou a se alimentar/comer'

d. na-powae -ü

3P-pescar-CONTINUATIVO

'ele ainda está pescando, ele continua/continuou a pescar'

O sufixo -etcha 'habitual' indica uma situação que ocorre sempre, como se vê nos dados em (10):

(10) a. tcha-goe-etcha 1P-torrar massa- HABITUAL

'eu vivo torrando massa'

b. tcha-powae-etcha

1P-pescar [com vara]-HABITUAL

'eu vivo pescando'

c. tcha-tchibü-etcha

1P-alimentar, comer-HABITUAL

'eu vivo comendo/ me alimentando'

c. . i-tcha-nha-ãtchi-etcha

PROGRESSIVO-1P-fugir- DURAÇÃO CURTA, LIMITADAHABITUAL

'eu sempre estava dando uma corridinha'

O caráter verbal da forma em que se fazem presentes os sufixos - $\tilde{u}$ ‘continuativo' e -etcha 'habitual’ não provém da marca de pessoa que, como prefixo, está nessas mesmas formas, uma vez que tal marca ocorre em formas quer verbalizadas, quer nominalizadas, como comprovam os dados a seguir, em 
que a marca de terceira pessoa por si só não garante a categorização da forma que integra como verbal ou nominal: ${ }^{48}$
a. cu-ü na- ngüe
b. cu-ü na- ngüe-ü
2P-'DAT(BEN)' 3P-ajudar- NMLZR
'ajuda dele a você'

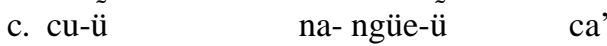 2P-'DAT(BEN) 3P-ajudar- NMLZR FINALIDADE 'para a ajuda dele a você'

No quadro de uma teoria em que categorias funcionais definem a categoria sintática do que são raízes neutras em termos categoriais (e cujo percurso em parte retraçamos) fica excluída a possibilidade de ser a marca de pessoa o elemento caracterizador de uma categoria lexical em Ticuna. Considerando-se que, no quadro dessa teoria, a propriedade categorizadora é atributo de um núcleo funcional, os mais sérios candidatos a núcleo funcional nos dados em (11) são um v-zinho fonologicamente nulo (11a) e um n-zinho materializável através de um morfema nominalizador (11b e 11c), aí responsáveis, respectivamente, pela constituição das categorias verbo e nome (...na-ngüe 'ele ajuda'; na- ngüe-ü̈ 'ajuda dele...'). As configurações que correspondem aos dados em (11) e que abrigam os mencionados núcleos se encontram em (12). Nessas configurações, a base acategorial inclui a raiz, e, durante o processo derivacional, a estrutura acategorial (e aquela que essa vier a integrar) será adjungida $^{49}$ a um núcleo funcional, em movimento para a esquerda, devido a um traço forte que, possuído por esse núcleo, é desencadeador do movimento, o qual, por sua vez, mantém um elo com o que será a linearização da sequência final.Vale ressaltar que, no mesmo quadro teórico em tela, nomes e verbos não são nódulos terminais sem qualquer estrutura interna - o que é compatível com a visão de que nódulos não ramificantes constituem uma impossibilidade ${ }^{50} \mathrm{e}$, portanto, exigem reanálise.Em se tratando das representações em (12), a (re)análise que impede a existência de nódulos não ramificantes é aquela que se apoia na detecção de um elemento funcional fonologicamente nulo $(v)$, que levará 
uma base (no caso, uma raiz neutra em termos categoriais) a se tornar verbo (12a) e integrará uma sequência que poderá se tornar um nome (12b). Para além da assunção teórica, é preciso registrar que a proposta da existência de raízes/bases neutras (isto é, acategoriais) em Ticuna recebe um suporte empírico indireto, quando falantes são capazes de espontaneamente optar por elas como entradas de verbete durante o processo de elaboração de um dicionário ${ }^{51}$ de sua língua e de, no mesmo verbete, ao exemplificar seu uso em uma sentença, manter seu significado nuclear e lançar mão dos recursos morfológicos/sintáticos necessários à sua categorização e consequente utilização sintática como nome ou verbo. Essa evidência indireta aponta na direção de uma categorização lexical dependente de especificação sintática.

(12) a.

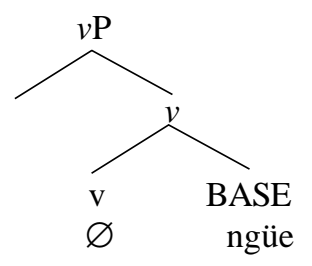

Configuração inicial para a obtenção da categoria verbo a partir de $v$ (fonologicamente nulo) combinado a uma base acategorial.

(12) b.

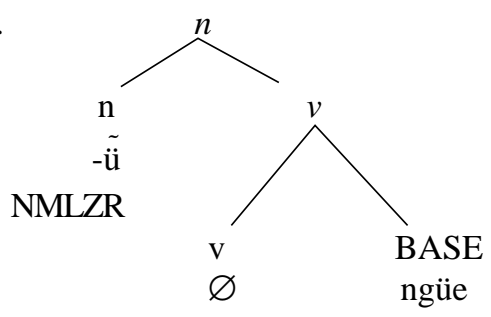

Configuração inicial para a obtenção da categoria nome a partir de $n$ materializável através de morfema nominalizador

Na mesma linha de raciocínio, observemos os sufixos - ü “continuativo” e -etcha 'habitual', que se manifestam, conforme nossos dados, apenas em formas verbais. A primeira hipótese é a de que são candidatos a verbalizador. Nessa condição, alternariam com o v-zinho fonologicamente nulo e, como esse, seriam capazes de fazer com que a base morfológica acategorial à qual se 
agregam torne-se um verbo. Em outros termos, os aspectos continuativo e habitual - noções aspectuais materializadas no verbo Ticuna como sufixos - são tratáveis no âmbito da projeção do pequeno verbo ou v-zinho, e, na condição de verbalizadores, constituiriam eles próprios um pequeno verbo. A exemplificação das configurações correspondentes a essa hipótese encontra-se a seguir: em (13a), tem-se a configuração para a obtenção de um verbo a partir de um v-zinho materializado como morfemas aspectual e, em (13b), o momento sintático posterior em que, derivacionalmente, a base-estrutura acategorial que contém a raiz - se adjunge ao $v$-zinho, em movimento obrigatoriamente para a esquerda: ${ }^{52}$

(13) a.

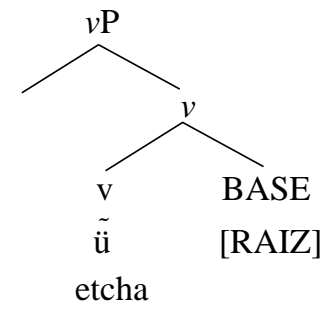

Configuração inicial para a obtenção da categoria verbo a partir de $v$ materializado por morfema aspectual e combinado a uma base acategorial

(13) b.

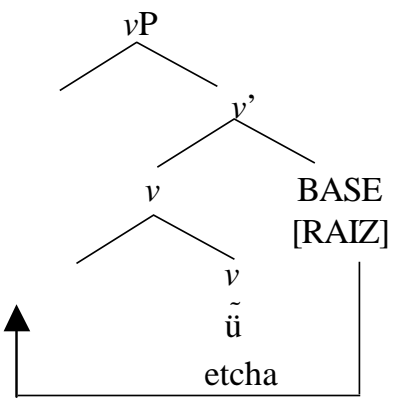

Adjunção da base acategorial [ Raiz] ao $v$ materializado por morfema aspectual

Na condição de hipótese alternativa àquela que (13a) e (13b) expressam, estaria uma segunda possibilidade, que é a de serem os sufixos em questão combináveis a uma base já verbalizada, nos termos do que foi indicado em (12). Nesse caso, ter-se-ia que impor, por estipulação, uma restrição relativa à adição de tais sufixos a nomes derivados - o que levaria a um custo analítico adicional. 
Ainda ligados a essa segunda possibilidade de análise, estariam determinados desdobramentos. De um lado, considerar os sufixos - ̃ü ‘continuativo' e -etcha 'habitual' como um tipo de v-zinho combinável a uma base já verbalizada por um outro v-zinho - aquele fonologicamente nulo - implicaria não somente uma sobreposição (já que ambos seriam passíveis de conter a propriedade da verbalização), mas também acarretaria a admissão de combinação irrestrita entre um v-zinho mais alto e um v-zinho mais baixo - em uma direção de análise contrária a dos casos em que, teoricamente, essa proposta se sustentou. ${ }^{53} \mathrm{De}$ outro lado, considerar os sufixos -ü ‘continuativo' e -etcha 'habitual' como sufixos neutros, acategoriais, seria ampliar o conjunto das estruturas com as quais esses podem ocorrer - o que os dados disponíveis sobre a língua não confirmam. Diante de tais desdobramentos e do custo analítico anteriormente apontado, a nossa opção de análise segue a primeira hipótese, pela qual os sufixos em tela constituem verbalizadores que alternam com o v-zinho fonologicamente nulo e são aplicáveis a raízes ainda não categorizadas.

No verbo em Ticuna também se materializam, por meio de formas sufixais, duas outras noções aspectuais: -ãtchi ‘duração curta, limitada' e -cü'ü 'ação repetitiva e rápida’. Diferentemente, porém, do que vimos em relação aos aspectos 'continuativo' e 'habitual', os sufixos -ãtchi e -cü'ü integram estruturas que tanto servem a nomes como a verbos, não levando, portanto, à identificação categorial dessas estruturas (o que significa dizer que as estruturas de que fazem parte são acategoriais).Exemplos: ${ }^{54,55}$

\section{(14) a. ni-pe-ãtchi}

3P-dormir- DURAÇÃO CURTA, LIMITADA

'ele tirou uma soneca/cochilou'

b. pe-ãtchi

dormir-DURAÇÃO CURTA, LIMITADA

'cochilar / cochilo, soneca'

c. bua-cü'ü

?-AÇÃO REPETITIVA E RÁPIDA

'que balança/ balançante'

d. tcha-ya-bua-cü'ü 1PS-OI-?-AÇÃO REPETITIVAE RÁPIDA

'balancei-o' 
Como evidenciam os exemplos em (14), os morfemas -ãtchi duração breve/limitada e -cü'ü ação repetitiva e rápida do evento juntam-se a uma raiz sem ser capazes de categorizá-la e, em razão disso, são parte de uma base acategorial (ou seja, tais morfemas são acategoriais e combinam-se a uma raiz também acategorial, constituindo uma base estendida). A representação formal desse fato encontra-se em (15), em que a combinação [RAIZ + ãtchi] ou [RAIZ + cü'ü] (base acategorial) é adjungida, em movimento obrigatoriamente para a esquerda, ao pequeno verbo ou v-zinho, que, verbalizando essa estrutura, é, nesse caso, fonologicamente nulo.

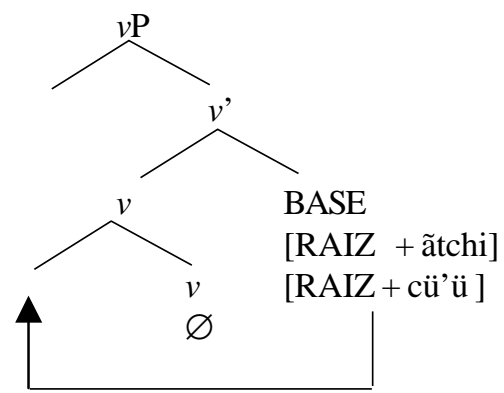

Adjunção da base acategorial [Raiz + ãchi] / \{Raiz+ cü’ü] ao $v$ fonologicamente nulo

Os fatos relativos às noções aspectuais que, no verbo Ticuna, se materializam como sufixos possuem uma íntima relação com a constituição de expressões idiomáticas nessa língua - o que retomaremos na seção 4. Esses mesmos fatos apoiam: de um lado, quando estão em jogo os sufixos -ü ‘continuativo' e -etcha 'habitual', o caráter verbalizador de v-zinho e, ainda, a dissociação entre as propriedades da transitividade e as propriedades semânticas dessa categoria funcional; de outro lado, no caso dos sufixos -ãtchi 'duração curta, limitada' e -cü’ü 'ação repetitiva e rápida', a existência de estruturas acategoriais das quais podem fazer parte determinadas noções aspectuais.A dissociação entre as propriedades da transitividade e as propriedades semânticas de $v$-zinho é, como vimos, uma proposta de Arad (1999) e está diretamente relacionada à própria fragmentação do núcleo funcional v-zinho em diferentes tipos, o que, por sua vez, é fruto das possibilidades de agrupamento de determinados traços relacionados às propriedades envolvendo esse núcleo. 
No sentido de saber o quanto a fragmentação proposta é ou não suficiente para se lidar com determinados sufixos verbais em Ticuna, passemos à expressão da causatividade nessa língua.

\subsection{Sufixo causativo}

Os dados do Ticuna até o momento obtidos revelam sempre um mesmo morfema causativo - -ẽeẽ - que, na sentença linearizada, é passível de redução fonológica (com presença ou não de oclusão glotal ${ }^{56}$ ) e sempre se mostra imediatamente à direita de uma raiz, tal como se vênas formas verbais de (16), a seguir. Note-se que aí, entre os marcadores de pessoa que acompanham a forma verbal, está uma terceira pessoa identificada através do gênero, sendo especificamente feminina (3PFEM - 16 c, d). A essa se contrapõe uma terceira pessoa não especificada para esse traço (3P - 16 a, b). Note-se também que há ainda uma outra terceira pessoa que, não especificada quanto ao gênero feminino ou não, apresenta, porém, traço de familiaridade, intimidade e/ou consideração, isto é, deferência por parte do falante em relação à pessoa de quem fala $(3 \mathrm{PF} / \mathrm{C}-16 \mathrm{e}, \mathrm{f}, \mathrm{g}) .^{57}$

(16)
b. na- nge'- ẽ ${ }^{-}$
3P-gostar-CAUS
c. i-nge'- ẽ'ẽ
3PFEM-gostar-CAUS
d. i-dawenü- ẽ'ẽ
e. ta-'au- ẽ'ẽ
3PFEM-olhar-CAUS
3PF/C -chorar-CAUS
3PF/C-OI-alimentar-se-CAUS
f. ta-na-tchibü- ẽ’ẽ
g. ta-na-pe-ẽẽ
'(ele) fez/causou chorar’ '(ele) fez/causou gostar' 'ela fez/causou gostar'
'ela fez/causou olhar'
'ele/ela fez/causou chorar'
'ele/ela fê-lo alimentar-se'
'ele/ela fê-lo dormir’

3P-chorar-CAUS

As formas verbais em (16) não foram obtidas como dados em lista (na realidade, integram sentenças), cabendo saber se, em Ticuna, é possível a existência de Causa desvinculada de um agente externo, ou seja, se é possível uma análise bieventiva de uma causativa inacusativa, tal como nos termos de Pilkkänen (2002), que busca, no âmbito dos causativos selecionadores de raiz, uma correlação entre a existência de causativos inacusativos e a possibilidade de causativização de inergativos (os verdadeiros intransitivos) e transitivos.

Com relação à questão acima, constata-se a existência, em Ticuna, de um conjunto expressivo de dados que, em princípio, apoiam a visão de um v-zinho 
causativo introdutor de um argumento externo. Vejam-se a propósito os dados a seguir, ${ }^{58,59}$ em que o causativo, a marca de pessoa na forma causativizada e o agente que essa marca recupera se encontram negritados:

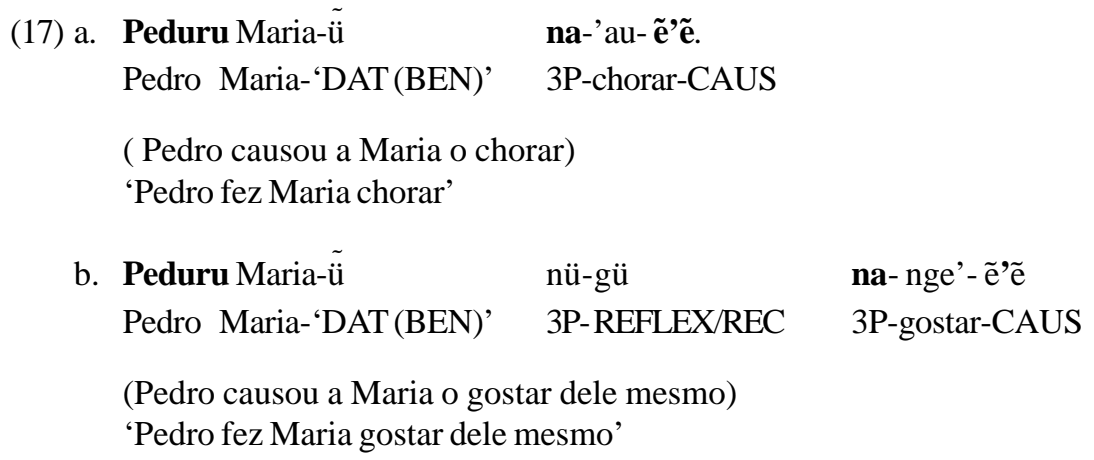

d. Mama ta-na-tchibü-ẽ’ẽ i bu'ü /

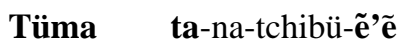
Mãe 3PF/C-OI-alimentar-se-CAUS x criança Ela [a mãe]...

(Mamãe a fez alimentar-se, a criança) / (Ela [a mãe] a fez alimentar-se, a criança) 'A mãe fez a criança alimentar-se' / Ela [a mãe] fez a criança alimentar-se'

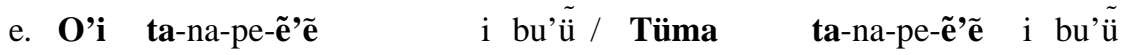
Avô 3PF/C-OI-dormir- CAUS x criança Ele [o avô]...

(O avô a fez dormir, a criança) / (Ele [o avô] a fez dormir, a criança) 'O avô fez a criança dormir' / Ele [o avô] fez a criança dormir'

Ao lado dessas sentenças, há um outro conjunto de dados que nos permite não só problematizar a relação entre a marca de pessoa na forma causativizada e um agente externo, mas também considerar a questão de ser ou não possível, em Ticuna, a existência de Causa desvinculada da introdução desse mesmo agente externo.Consideremos os dados em (18): ${ }^{.0}$ 
a. ...natürü tchama rü Tunetüwa tcha-ya, então eu TOP Tunetü LOC 1P-criar, crescer

'Então eu me criei/ cresci no Tunetü...'

(SOARES 1984; (Texto; P.I))

b. O’i ai na-ya-ẽ'ẽ

Avô onça 3P-criar, crescer-CAUS

'O avô (ou vovô) criou a onça/ O avô fez a onça se criar'

(SOARES, 2009; dado 11a (G))

c. O’i-tchiga ya ai na-ya-ẽ'ẽ -cü

Avô-notícia, história, fama $\mathrm{x}$ onça 3P-criar, crescer-CAUS-NMLZR

'História do avô que fez a onça se criar/crescer' (SOARES, 2009; dado 11b (Z))

d. O’i ya ai ya-ẽẽ-cü arü ore

Avô x onça criar, crescer-CAUS-NMLZR de história

'História do avô criador de onça' / História do avô que fez a onça se criar/ crescer'

(cf. SOARES, 2000, p. 71; dado 2.67)

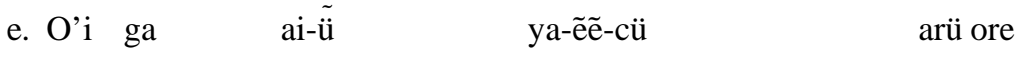

Avô x (PASS) onça-'DAT (BEN) criar,crescer-CAUS-NMLZR de história

(SOARES, 2009; dado 11b (D))

'História do avô criador de onça' / História do avô que fez a onça se criar/ crescer'

Esses últimos dados exibem uma forma que contém a raiz referente a 'criar, crescer', semanticamente reveladora de uma mudança de estado. Entre as construções exemplificadas, (18a ${ }^{61}$ é aquela que não apresenta o verbo sob a forma causativa, e o seu único argumento - tchama 'eu' - se manifesta na posição de tópico (TOP). As demais apresentam como suposto agente causador o'i 'avô' (palavra bastante valorizada e objeto de respeito no universo Ticuna) e, ainda, causativização da forma referente a 'criar, crescer', mostrando que, no quadro do causativo possivelmente selecionador de raiz em Ticuna, encontra-se causativização de inacusativo. ${ }^{62} \mathrm{Em}$ (18b), a forma verbal com causativo recebe marcador de pessoa que pode não estar relacionado ao argumento externo, e sim ao argumento interno de 'criar', crescer' ( $a$ i 'onça'). Em (18c), a forma com causativo é nominalizada e mantém essa mesma marca de pessoa. Em (18d, e), a forma causativizada e nominalizada a dispensa - o que mostra que, em contexto de nominalização, a forma causativizada pode ser desvinculada da marcação de pessoa e que, em detrimento dessa última, é mais importante, aparentemente, fazer sobressair aí o próprio evento que ela veicula. 
Voltando-nos para a hipótese de que formas causativizadas podem encerrar a referência a um evento sem a exigência de vinculá-lo a um argumento externo, tem-se que, nos exemplos em (18) que apresentam forma causativizada, a marca pessoal, quando presente, diz respeito a uma terceira pessoa que não revela traço de deferência por parte do falante em relação à pessoa de quem fala e que seria supostamente um agente causador - traço que poderia ser esperado por estar em jogo nessas sentenças a palavra o' $i$ 'avô'. ${ }^{63}$ Pode-se explicar essa situação, se adotada uma análise bieventiva de construções causativas do Ticuna, análise segundo a qual um núcleo funcional Causa introduz apenas um evento causativo à semântica da construção. Hipótese conectada à existência de causativização de inacusativos na língua, essa recebe uma confirmação através de outros dados, como aqueles em que construções causativas em Ticuna são desdobráveis em termos sintáticos por um grande grupo de falantes dessa língua no Brasil:

a. Mepü'üna i-na-ü [na Mecüracü Mematüna-ü

Mepü'üna 3PF-OI-fazer CONEC Mecüracü Mematüna-'DAT (BEN)’

na-dawenü-ẽ’ẽ -ü].

3P-olhar-CAUS- NMLZR

(Mepü'üna o fez, o causar Mecüracü olhar Mematüna)

'Mepü’üna fez Mecüracü olhar/cuidar da Mematüna'

b. Na-na-ü ya Mecüracü [na Mematüna bucu-ü

3P-OI-fazer x Mecüracü CONEC Mematüna menino-DAT (BEN)'

na-dau-ẽẽ ë-ü]

3P-ver-CAUS-NMLZR

(Fê-lo, o Mecüracü, o causar Mematüna ver/cuidar do menino)

'Mecüracü fez Mematüna ver/cuidar do menino'

c. Na-na-ü ya Mecüracü [na Mematüna-ü na-dau-ẽe-eü 3P-OI-fazer x Mecüracü CONEC Mematüna-DAT(BEN) 3P-ver-CAUSNMLZR

(Fê-lo, o Mecüracü, o causar a Mematüna o ver/ o cuidar [dele, do menino])' 'Mecüracü fez Mematüna ver/cuidar [do menino]' 
O desdobramento sintático de construções causativas exibido em (19) revela uma segunda oração cuja característica maior é a de apresentar uma forma verbal nominalizada ${ }^{64}$ e a de ser anunciada, localizada sintaticamente por uma marca interna ${ }^{65}$ ao verbo da oração matriz. Em (19a), o argumento externo (suposto agente causador) integrante da oração matriz é um nome próprio feminino na língua (Мepü'üna) e o marcador de pessoa encontrado na forma causativizada integrante de um verbo nominalizado (segunda oração) não revela traço de gênero correspondente ao que se esperaria para esse suposto agente: a marca de pessoa que se apresenta não é a de terceira pessoa feminina ( $i-$-), e sim a de uma terceira pessoa que, não especificada para gênero feminino (na-), pode ser relacionada ao evento causador ou, como hipótese alternativa, a Mecüracü, termo da segunda oração de (19a) expresso por nome próprio masculino e referente àquele que é levado a 'olhar/cuidar'. Essa hipótese alternativa não se sustenta, porém, ao considerarmos dados como (19b) e (19c). A terceira sentença, (19c), é mais facilmente aceita do que a segunda, (19b), possivelmente porque nela está subentendido bucü ‘menino’ (aquele que é olhado/cuidado), já mencionado anteriormente no discurso, o que leva a marcação casual de dativo (benefactivo) a recair sobre o termo referente a quem é levado a olhar/cuidar (Mematüna). Apesar disso, ambas as sentenças apresentam como suposto agente causador um nome próprio masculino na língua (Mecüracü) e repetem, na forma causativizada da segunda oração, o mesmo marcador de pessoa (na-) já visto em (19a), sendo que, desta vez, na segunda oração de (19b) e (19c), está um nome próprio feminino: Mematüna, aquela que é levada a 'olhar/cuidar'. Ou seja: o marcador de pessoa na- não possui traço compatível com argumentos femininos - o que mostra que não pode ser controlado nem pelo argumento causador (19a), nem pelo argumento cujo agir foi causado (19b, c); e que, portanto, deve ser outra a sua origem nas sentenças acima. Excluída a possibilidade de ser o argumento feminino aquele a que se vincula o marcador de pessoa em questão em (19a, b, c), o único meio de se obter uma solução uniforme para o aparecimento em Ticuna da marca de terceira pessoa que, não especificada para gênero feminino (na-), ocorre em construções causativas desdobráveis em termos sintáticos é admitir que essa está relacionada ao evento causador, e não a um argumento externo (o suposto agente causador). Com isso, torna-se possível também explicar determinadas situações mencionadas anteriormente e encontradas nas construções causativas do Ticuna 
que não se apresentam sintaticamente desdobradas. Da mesma forma, é possível compreender a causativização de inacusativos na língua (cuja configuração sintática não prevê lugar para argumento externo). Assim, por suas vantagens diante de fatos da língua Ticuna, assumimos uma análise bieventiva de construções causativas dessa língua nos termos de Pilkkänen (2002). Por essa análise, a interpretação de sentenças como aquelas já vistas em (18) será, respectivamente, 'o avô foi o agente de um evento que causou a criação/ o crescimento da onça' (18b); 'a história do avô que foi o agente de um evento que causou a criação/ o crescimento da onça' (18c, d, e). Já aquelas constantes de (19) terão, por sua vez, uma interpretação próxima daquela fornecida entre parênteses por ocasião da apresentação desses últimos dados, ou seja: 'Mepü'üna o fez, o ser agente de um evento que causou a Mecüracü olhar Mematüna' (19a); 'Fê-lo, o Mecüracü, o ser agente de um evento que causou Mematüna ver/cuidar do menino (19b); 'Fê-lo, o Mecüracü, o ser agente de um evento que causou a Mematüna o ver/ o cuidar [ dele, do menino] ' (19c). E, com relação àquelas sentenças como as que estão em (17), em que a marca de pessoa na forma causativizada recupera claramente o agente - ou experienciador ou qualquer outro papel temático possível para argumentos externos -, poderíamos dizer, acompanhando Kratzer (1996), que aí são visíveis os efeitos da regra de identificação de Evento. ${ }^{66}$

Assumida uma análise bieventiva de construções causativas do Ticuna nos termos de Pilkkänen (2002) e contrariamente a Harley (2006), as evidências que conseguimos reunir colocam essa língua como integrante do conjunto daquelas que não agrupam Voz e Causa em um único núcleo funcional (Non-Voicebundling Cause languages). No que diz respeito ao complemento selecionado pelo causativo, os dados por nós coletados indicam que esse é uma raiz. As evidências apontam sempre para a seleção de uma raiz por parte do causativo e para a inexistência de uma morfologia verbalizante entre o morfema causativo e a própria raiz. Some-se a isso o fato de que, no que diz respeito à modificação adverbial, os dados de que dispomos confirmam igualmente as previsões da tipologia proposta por Pilkkänen (2002): uma vez presente um advérbio, esse tem escopo apenas sobre o evento causador, estando excluída uma leitura em que advérbio também poderia ter escopo sobre o evento causado. Assim, em (20) a seguir, o advérbio cuja tradução mais próxima é 'precisamente devagar, com calma’ não pode ter também alcance sobre o evento causado (a criança se 
alimentar, comer), mas apenas sobre o evento causador. O mesmo se dá com relação ao advérbio paama 'rapidamente', na sentença seguinte, (21), em que é o evento que causa, faz o menino dormir que se dá de modo rápido, e não o próprio o evento causado (o menino dormir). ${ }^{67}$

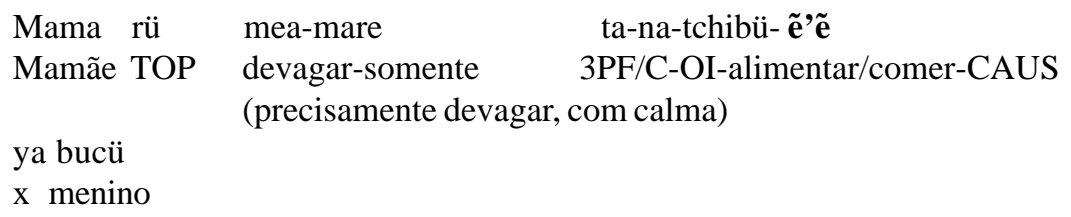

(Em se tratando da mãe, ela foi agente de um evento que, precisamente devagar, fez o menino se alimentar)

'A mãe, com calma, fez o menino se alimentar' / A mãe fez, com calma, o menino se alimentar/

* A mãe fez o menino se alimentar com calma.

(21) O’i rü paama ta-na-pe-ẽẽ ẽ ya bucü

Avô TOP rapidamente 3PF/C-OI-dormir-CAUS x menino

( $\mathrm{O}$ avô foi o agente de um evento que rapidamente fez o menino dormir)

'O avô rapidamente fez o menino dormir' / * O avô fez o menino dormir

rapidamente’

Tais fatos podem encontrar sua explicação na hipótese de ser uma raiz o complemento do causativo em Ticuna - e não um verbo já categorizado como tal ou uma nova fase que resulte na introdução de um argumento externo (o que, conforme vimos, nos termos de Pilkkänen (2002) se dá através do núcleo Voz, no interior de um sintagma Voz - VoiceP). E os mesmos fatos também possuem uma íntima relação com a constituição de expressões idiomáticas nessa língua.

\section{Fronteiras para a constituição de expressões idiomáticas em Ticuna a partir de sufixos de aspecto e causa: expectativas e algumas conclusões}

Os sufixos aspectuais - ü ‘continuativo' e -etcha 'habitual' estão, pela análise efetuada, na condição de verbalizadores.No contexto do percurso teórico traçado, é possível prever que as formas que se fazem acompanhar desses verbalizadores integrem expressões idiomáticas em Ticuna, mas sob condição, 
isto é, desde que nada do que esteja hierarquicamente acima da categoria funcional pequeno verbo ou $v$-zinho possa servir como contexto para significado especial de qualquer raiz abaixo dessa categoria.Isso porque $o$ domínio de localidade para a existência de significado especial coincide assumimos aqui - com a fronteira do pequeno verbo. Mas como nenhuma expressão idiomática poderá ser integrada por um agente fixo, conforme Marantz (1997), a raiz que se junte aos verbalizadores em questão, para formar uma expressão idiomática em Ticuna, ou terá uma interpretação não agentiva ou, envolvendo argumento acima de v-zinho, apresentará um eventual argumento externo agente impedido de determinar um significado idiomático do qual ela participe. Exemplos de possíveis integrantes de expressões idiomáticas na língua seriam, por exemplo as raízes não agentivas e combináveis aos verbalizadores em questão, como pe 'dormir', ya 'criar-se, crescer'.

Quanto aos sufixos aspectuais -ãtchi ‘duração curta, limitada' e cü’ü 'ação repetitiva e rápida', que integram estruturas acategoriais e que não envolvem, no processo de sua combinação, argumento acima de v-zinho, a expectativa é a de que esses estejam na condição de grandes fornecedores de expressões com significado especial, em que o significado do todo não é, digamos, o somatório dos significados das partes constituintes e em que domínio de localidade e imposições sobre a raiz (ou raízes) estariam respeitados. Exemplo disso encontra-se na combinação da raiz cua' 'saber' e do sufixo -ãtchi 'duração curta, limitada', em (22). O resultado dessa combinação é o significado especial (idiomático) ‘lembrança/lembrar’ (22a), que, ao estar no âmbito de $v$-zinho acompanhado por um clítico ou um complemento com o papel de meta (22b), se mantém em um domínio de localidade do qual está excluído um agente: aí, conforme previsto por Marantz (1997), a base acategorial constituída se submete a essa condição linguística para manter-se como expressão idiomática.

(22) a. cua'-ãtchi 'lembrança, lembrar' saber-DURAÇÃO CURTA, LIMITADA

b. nü-na ta-cua'-ãtchi-e [ga pawü arü tü ] 3P-META 3P-saber-DURAÇÃOCURTA, LIMITADA-PL x aranha de fio, linha 'lembraram-se dele, do fio da aranha' 
Com relação ao sufixo causativo (-ẽ’ẽ) do Ticuna, o fato de esse ser sempre selecionador de uma raiz da qual não é separado por uma morfologia verbalizante também permite esperar que o mesmo seja um fornecedor por excelência de expressões idiomáticas. Os exemplos em (23) são prova disso: (23a) apresenta como complemento do causativo a raiz wüca 'caçar com espingarda' e o resultado, na condição de significado especial, não quer dizer ‘causar caça com espingarda', mas ‘arranjar um parceiro’, indo atrás de um homem ou uma mulher; (23b) contém a raiz woma 'enganar' acompanhada do causativo, daí resultando o significado especial 'comer', no lugar de uma soma de partes cujo resultado, a princípio, seria ‘causar engano’. E como os dados da língua fornecem indicações de que essa pode não agrupar Voz e Causa, a presença do causativo em Ticuna já excluiria de antemão a introdução de argumento externo - algo que toda expressão idiomática deve deixar de fora.

(23a) Ngiã ta-wüca- ẽ’ẽ-gü 'vamos arranjar homem/mulher' EXORTATIVO 1PPL- caçar com espingarda-CAUS-PL

b) Paa yi-gü ta-woma-ẽ'ẽ-gü

ORDEM[PARAAÇÃORÁPIDA] 1PPL-REFLEXIVO 1PPL-enganar-CAUS-PL 'vamos comer'

O exame efetuado de sufixos aspectuais e do causativo no domínio de $v$ em Ticuna nos leva a comprovar que os aspectos do significado aí determinados pela sintaxe excluem o agente externo. A análise realizada apoia o caráter verbalizador de $v$-zinho, a dissociação entre as propriedades da transitividade e as propriedades semânticas dessa categoria (ARAD, 1999) - essencial para o tratamento de sufixos aspectuais na língua estudada. No âmbito da causatividade, a fragmentação de v-zinho em diferentes tipos necessita, porém, levar em consideração a possibilidade da separação formal entre Voz eCausa (PILKKÄNEN, 2002). No que diz respeito ao causativo, o tipo de complemento selecionado por esse é fundamental para a constituição de uma expressão idiomática. Ou v-zinho CAUSA tem como seu complemento um sintagma da raiz $(\sqrt{ } \mathrm{P})$ e dá lugar a interpretações idiomáticas (conforme HARLEY, 2006) ou, em outros termos, porém de modo similar, um núcleo Causa pode selecionar como seu complemento a raiz, propiciando igualmente a existência de expressões idiomáticas (PYLKKÄNEN, 2002). 


\section{Notas}

* O presente trabalho vincula-se à execução do Projeto "Línguas da Amazônia Brasileira: Variação, Cognição e Estudos de Fonologia, Gramática e História”, apoiado pelo CNPq e pela FAPERJ - através, respectivamente, de bolsa de produtividade em pesquisa e auxílio / taxa de bancada à pesquisa. Agradeço aos membros do GT de Línguas Indígenas da ANPOLL e do GT A Tarefa da Tradução Cultural em Antropologia da ABA que, em 2008, assistiram e realizaram observações a partes apresentadas deste trabalho. Agradeço também às colegas Marcia Damaso Vieira e Tania Clemente, com as quais dividi, no primeiro semestre de 2009, no Museu Nacional/UFRJ, um curso sobre questões de fonologia, morfologia e sintaxe de línguas indígenas brasileiras e no âmbito do qual pude compartilhar leituras sobre causatividade. Agradeço aos meus alunos e, sobretudo, ao parecerista que, com suas sugestões e críticas, permitiu que este artigo se enriquecesse. Eventuais equívocos são, porém, assumidos como meus.

${ }^{1}$ Vale observar que o Tempo em Ticuna não é expresso pela morfologia verbal e formalmente se separa da materialização aspectual. Para a questão do Tempo em Ticuna, veja-se Soares (2005).

${ }^{2}$ Em outras palavras, nem todas as noções aspectuais nessa língua integrariam uma projeção Aspecto. De acordo com a análise constante de Soares (2008), nessa projeção propriamente dita está o aspecto progressivo (manifestado por um prefixo), mas não outras noções aspectuais, de natureza afixal, tais como aquelas referentes ao ‘continuativo', ao 'habitual’, ‘à duração curta /limitada’, à ‘ação repetitiva e rápida’.

${ }^{3}$ Outros exemplos de construções com predicados de três lugares podem ser encontrados em línguas como o inglês e o português, que apresentam, respectivamente, sentenças do tipo He broke the vase into pieces/Ele quebrou o vaso em pedaços e construções com verbos que demandam um complemento de lugar, como é o caso de put em inglês (She put her books on the shelf) e pôr, colocar em português (Ela pôs/ colocou seus livros na estante).Muitos predicados de três lugares podem ocorrer como predicados de dois lugares (por exemplo, em inglês, He broke the vase into pieces/ The vase broke into pieces; We rolled the ball down the hill; The ball rolled down the hill). Nessa situação, usados como predicados de três ou dois lugares, são às vezes chamados de predicados ergativos (cf. RADFORD 1997, p. 199).

${ }^{4} \mathrm{O}$ argumento benefactivo integrante das chamadas construções aplicativas (e conhecido por muitos como 'dativo de interesse') também é visto como um objeto indireto adicionado à estrutura de um verbo e, por conseguinte, passível de integrar construções com complemento duplo. (Exemplos em português: Cozinhei-lhe um ovo, Me apanha umas flores bem bonitas, entre outros.) 
${ }^{5} \mathrm{O}$ papel temático de beneficiário/ benefactivo também poderia ser incluído aqui (ver nota 4). Com relação ao papel temático de recipiente, esse é uma espécie de meta (goal) associada a uma noção de posse, ou seja, o papel temático de recipiente é portado pela entidade que recebe ou vem a possuir algo (cf. RADFORD, 1997, p. 270).

${ }^{6}$ Também conhecida como hipótese do sujeito interno ao VP (VP-Internal Subject Hypothesis) e ligada à idéia de que todos os papéis temáticos associados a um núcleo são atribuídos no interior das projeções desse núcleo, a hipótese do sujeito interno ao predicado coloca o local de origem dos sujeitos no interior do VP, mais claramente na posição de especificador, e essa posição é externa à projeção que domina imediatamente o verbo e o argumento interno. É essa posição externa (aquela do especificador da projeção em causa) que estará de fora de expressões idiomáticas e que poderá ou não ser projetada conforme o tipo de construção e a análise proposta. Voltamos a esse ponto em 2.3. (A propósito da posição dos sujeitos, ver KOOPMAN; SPORTISCHE, 1991; ver HORNSTEIN; NUNES; GROHMANN, 2005).

${ }^{7}$ A letra $e$ indica empty 'vazio'.

${ }^{8} \mathrm{O}$ papel temático externo é aquele do argumento externo, que se diferencia dos argumentos internos por não engatilhar interpretações especiais do verbo. A propósito, ver nota 6 e, ainda, Marantz (1984, p.22; 25-26; 40-41).

${ }^{9}$ (Cf. MARANTZ, 1984, p. 17-18; 167-168). Nesse trabalho, em substância, o autor separa a organização dos argumentos em um predicado - desempenhada pela função que o verbo nomeia - da atribuição de papéis semânticos a esses argumentos.

${ }^{10}$ Para ser gramatical, uma sentença como Paulo entregou sua própria sorte a Maria deverá apresentar correferência entre Paulo e sua (Paulo entregou sua ${ }_{j}$ sorte a Maria).

${ }^{11}$ Culicover; Jackendoff (2005, p. 117-119) mostraram que o c-comando sintático não é apropriado como condição exclusiva para a determinação de possibilidades anafóricas. É preciso registrar, porém, que a perspectiva adotada por esses autores difere daquela que eles próprios chamam de 'corrente principal da gramática gerativa', referente à linha de pesquisa estreitamente associada aos trabalhos de Noam Chomsky. Para ambos, a teoria sintática mais explanatória é aquela que, na mediação entre fonologia e significado, atribui a estrutura sintática mínima. Desse último ponto de vista, a busca por uma sintaxe mais enxuta se dá, necessariamente, através da admissão de uma interface sintaxe-semântica mais rica - o que permite aumentar o número de casos explicados em termos de propriedades semânticas/ pragmáticas e, consequentemente, simplifica a sintaxe. Outro registro importante é que a simplificação da sintaxe vem, no trabalho desses mesmos autores, acompanhada da possibilidade de estruturas mais “flat”, não sendo aí descartado o recurso a uma quantidade grande de princípios, aplicados em graus variados de regularidade. 
${ }^{12}$ Ver a propósito Jackendoff (1990) e Harley (2002).

${ }^{13}$ Nos termos de Larson, como aponta com olhar crítico Harley (2002, p. 31-32), "give a book to John" (construção com complemento duplo em inglês) é básica e "give John a book" (exemplificadora do dative shift) é derivada por meio de uma operação puramente sintática. Isso torna problemático o tratamento unificado de pares de sentença do inglês em que:

(i) o dative shift é possível ("The editor sent the article to Sue/The editor sent Sue the article"; "Susan kicked the ball to Max / Susan kicked Max the ball);

(ii) o dative shift é duvidoso ou impossível ("The editor sent the article to Philadelphia/ ??The editor sent Philadelphia the article"; "Susan kicked the ball out the window/* Susan kicked the window the ball”);

(iii) a potencialidade de um contraste semântico não se explica por meio de uma operação puramente sintática ("I knitted this sweater for our baby" 'Tricotei esse suéter para o nosso bebê' - em que o bebê pode ainda não ter nascido) /” I knitted our baby this sweater" 'Tricotei [para] nosso bebê esse suéter' - em que é forte a implicação de que o bebê já nasceu).

[Exemplos extraídos de Harley (2002, p. 37-38)].

${ }^{14} \mathrm{O}$ outro núcleo funcional proposto por Harley (2002) para essas construções é um elemento preposicional abstrato codificador de local $\left(\mathrm{P}_{\text {LOC }}-\right.$ nas construções com complemento duplo) ou posse $\left(\mathrm{P}_{\mathrm{HAVE}}\right.$ - nas construções com objeto duplo ou dative shift). O elemento preposicional proposto por Harley é núcleo de um sintagma preposicional complemento de v-zinho CAUSA. Como assinala a existência de expressões idiomáticas envolvendo o verbo e o tema (e não apenas o verbo e um sintagma preposicional como prevê Larson), Harley (2002, p. 43-44) procura manter a teoria restritiva de Larson das expressões idiomáticas como constituintes e introduz uma contraparte a $\mathrm{P}_{\mathrm{HAVE}}$, a saber: $\mathrm{P}_{\mathrm{LOC}}$, correspondente à “concha” VP mais baixa de Larson na estrutura com complemento duplo. Registramos que o tratamento da expressão da posse não está entre os nossos objetivos para o presente artigo.

${ }^{15}$ Os desenvolvimentos ulteriores aludidos dizem respeito ao Programa Minimalista, em que somente núcleos com traços entram na computação sintática - o que traz embutida a afirmação de que núcleos sem traços não entram na computação sintática (e, portanto, inexistem).

${ }^{16}$ A concepção de pequeno verbo ou v-zinho abertamente manifesto já se encontra, por exemplo (e de certa forma), em Hale; Keyser (1993, p. 99-101), quando, ao abordar verbos do Papago, esses autores focalizam a morfologia causativa aberta dessa língua. 
${ }^{17}$ Esse núcleo mais baixo, no trabalho publicado por Hale e Keyser em 1993, pode ser $\mathrm{V}$ ou $\mathrm{N}$. Um exemplo transparente de núcleo mais baixo $\mathrm{N}$ que se move em direção ao que ambos chamam de verbo matriz é encontrado em Jemez: - záae-'a (canção-fazer) 'cantar' (cf. HALE; KEYSER, 1993, p. 55).

18 "In reality, all verbs are to some extent phrasal idioms, that is, syntactic structures that must be learned as the conventional "names" for various dynamics events...In many languages a large percentage of verbal lexical items are overtly phrasal (e.g. Igbo...); in others a healthy inventory of "light verb" constructions represents the class of overtly phrasal lexical items (e.g. Japanese...; English); and in still others (e. g. the Tanoan languages, including Jemez, Tewa, and the Tiwa languages), the verbal lexicon contains an extraordinary number of entries whose morphological make-up is overtly the result of incorporation. To be sure, many languages boast a large inventory of simple monomorphemic verbs. But our guesses is that most, probably all, superficially monomorphemic verbs are lexically phrasal, possessing a structure that is syntactic... (HALE; KEYSER 1993, p. 96) [grifo nosso]

${ }^{19}$ Para Chomsky, as palavras saem prontas do léxico e são, então, submetidas à sintaxe.

${ }^{20}$ Na Morfologia Distribuída (Distributed Morphology), palavras estão internamente submetidas à sintaxe, explodindo-se a noção de léxico tal como essa é concebida em uma visão lexicalista (pela qual a sintaxe manipularia palavras sem ter acesso à sua constituição interna).

${ }^{21}$ Verbos intransitivos inacusativos são aqueles cujo único argumento se comporta como argumento interno. São exemplos de verbos inacusativos em português: abrir, fechar, chegar, ir, vir, quebrar, morrer, entre outros.

${ }^{22}$ A propósito, reveja-se a nota 14.

${ }^{23}$ Cf. Harley (2006, p. 27-28).

${ }^{24}$ Lembramos que, em Harley (2002), v-zinho CAUSA toma como seu complemento - em construções com complemento duplo e com dative shift - um sintagma preposicional.

${ }^{25}$ Aplicados ao japonês, os testes em questão envolvem escopo, controle adverbial, vinculação/ ligação (binding) e disjunção (conjugação de eventos através do disjuntivo -ka 'ou', tendo-se um único morfema causativo).

É preciso ressalvar que outros testes - que envolvem polaridade negativa, Tempo e Caso - revelam, por outro lado, o caráter mono-oracional das chamadas causativas sintáticas do japonês.

${ }^{26}$ Ver nota 20. 
${ }^{27}$ Cf. Pylkkänen (2002, p. 13; 90).

${ }^{28}$ A regra em questão é a de Identificação de Evento (Event Identification).

${ }^{29}$ Com isso, Pylkkänen exclui a introdução de um novo argumento sintático como propriedade nuclear da causativização (cf. PILKKÄNEN, 2002, p. 75).

${ }^{30}$ Em línguas do tipo Voice-bundling Cause, Voz e Causa constituem uma unidade apenas em termos sintáticos, não podendo se combinar semanticamente. Isso quer dizer que é estrutural - e não semântica - a diferença entre as línguas do tipo Voicebundling Cause e aquelas que recaem no tipo Non-Voice-bundling Cause (cf. PYLKKÄNEN, 2002, p. 91-92).

${ }^{31}$ Está nesse caso a chamada causativa 'adversativa' do japonês, em que o argumento nominativo não é interpretado como um causador, mas antes como um argumento afetado do evento descrito pelo verbo. Exemplo disso está na leitura adversativa da sentença Taroo-ga musoko-o sin-ase-ta (Taro-NOMINATIVO filho-ACUS morrer-CAUSA-PASSADO) 'Para o mal / prejuízo de Taroo, o filho morreu'. Na condição de causativa adversativa, uma sentença não pode ser colocada na voz passiva, o que prova, se seguirmos o raciocínio de Pylkkänen, que o argumento nominativo não é um argumento externo (agente).

${ }^{32}$ Exemplo desse tipo de interveniência morfológica pode ser visto no dado a seguir do japonês. Ao se fazer presente entre a raiz e o morfema causativo, o morfema desiderativo (DES) torna impossível a interpretação adversativa (ver nota 31), diagnosticadora, no japonês, das causativas lexicais (em que o causativo é selecionador de raiz ):

Taroo-ga musuko-o sini-taku-sase-ta.

Taro-NOM son-ACC die-DES-CAUSE-PAST

Taro-NOM filho-AC morrer-DES-CAUS-PASSADO

(i) 'Taro made his son want to die' / 'Taro fez seu filho querer morrer'

(ii) *'Taro was adversely affected by his son wanting to die / '*Taro foi adversamente (isto é, para seu prejuízo) afetado pelo querer morrer de seu filho' (Cf. PYLKKÄNEN, 2002, p. 99)

${ }^{33} \mathrm{Na}$ configuração em que a categoria funcional Causa seleciona uma raiz como seu complemento (7a), o esperado é que, uma vez presente um advérbio, esse tenha seu escopo apenas sobre o evento causador, de modo a não ser desfeita uma possível leitura idiomática, propiciada justamente pelo fato de ser uma raiz o complemento de Causa.Um exemplo disso é a manutenção, na chamada causativa lexical do japonês, da leitura adversativa (idiomática) quando, presente um advérbio, 
esse tem escopo somente sobre o evento causador; ao ser alterado o escopo do advérbio, tem-se a impossibilidade dessa leitura:

Taroo-ga musuko-o isagiyoko sin-ase-ta

Taro-NOM son-ACC bravely die-CAUSE-PAST

Taro-NOM filho-AC bravamente morrer-CAUS-PASSADO

(i) 'Taro bravely caused his son to die' / 'Taro bravamente fez o seu filho morrer'

(ii) *'Something caused Taro to be adversaly affected by his son dying bravely/

*Algo fez Taro ser adversamente afetado pelo morrer bravamente de seu filho.

No que diz respeito à configuração em que a categoria funcional Causa seleciona um verbo já categorizado como tal (7b), o advérbio, sem se orientar para o agente, pode ter também escopo sobre o evento causado - situação com exemplo em finlandês:

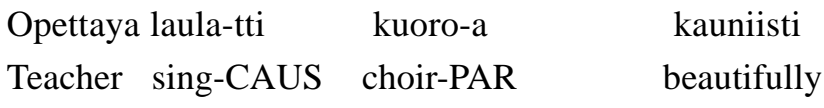

Professor cantar-CAUS coro-PARTITIVO lindamente

'The teacher made the choir sing beautifully' / 'O professor fez o coro cantar lindamente'

(Teacher’s action does not need to be beautiful/ A ação do professor não necessita ser linda)

Por fim, com relação à configuração em que Causa seleciona uma nova fase, é possível encontrar modificação efetuada pelo advérbio com escopo sobre o agente mais baixo. Exemplo disso é encontrável em Venda, uma língua bantu:

Muuhambadzi o-reng-is-a Katonga modoro nga dzangalelo Salesman 3SG.PAST-buy-CAUSE Katonga car with enthusiasm Vendedor 3SG.PASSADO-comprar-CAUS Katonga carro com entusiasmo 'The salesman made Katong BUY THE CAR EAGERLY'/ 'O vendedor fez Katonga COMPRAR O CARRO COM ENTUSIASMO’.

(Ver a respeito PYLLKÄNEN, 2002, p. 99; 107-108).

${ }^{34}$ Cf. Pylkkänen (2002, p. 77- 80).

35 "The different structural realizations of the functional element CAUSE predict that unaccusative causatives should be possible in Japanese and Finnish but not in English.” (cf. PYLKKÄNEN, 2002, p. 92).

${ }^{36}$ Por razões didáticas, mantemos aqui a projeção intermediária v’. 
${ }^{37}$ Cf. Arad (1999, p. 12-14).

${ }^{38}$ Arad não define o conteúdo semântico de v-zinho de maneira precisa, limitandose a levantar possíveis opções (cf. ARAD, 1999, p. 11).

${ }^{39}$ Lembrar que Pylkkänen (2002), inspirando-se em Kratzer (1996), afirma que essa é uma propriedade de Voz (Voice), e não de v-zinho.

${ }^{40}$ As construções do japonês que Arad (1999) toma como exemplos são aquelas com o sufixo rare 'poder' que, tratado como um verbo mais alto, faz com que o verbo mais baixo na representação sintática fique impedido de manifestar caso acusativo no que seria seu complemento, passando a sentença a exibir dois argumentos no caso nominativo (o exemplo crucial fornecido é Emi-ga ringo-ga tabe-rare-ru (Emi-NOMINATIVO maçã-NOMINATIVO comer-poder- PRS) 'Emi pode comer a maçã').

${ }^{41}$ Nas línguas românicas, o exemplo que exibe a perda da propriedade da transitividade, segundo Arad (1999), está nas construções com clítico reflexivo (em que o núcleo $v$-zinho formador de reflexivo não apresentaria a propriedade da transitividade).

${ }^{42}$ Nunca é demais lembrar que as construções passivas revelam uma forma verbal intransitivizada juntamente com uma interpretação agentiva.

${ }^{43}$ Exemplos de construções verbais com objeto experienciador podem ser encontrados, entre outras línguas, em espanhol (la música le molestó 'a música o incomodou'), em inglês (Anna's behaviour frightens Laura 'o comportamento de Ana assusta Laura), em italiano (Questo piacce a Gianni 'Isso agrada a Gianni’), em português (Isso incomoda Maria). (Ler a propósito ARAD, 1999, p. 4-10;12-14).

${ }^{44}$ É o que se dá, por exemplo, quando Arad (1999, p. 13-14) aborda, em construções com objeto duplo, o v-zinho aplicativo como núcleo funcional dominado por vzinho ativo: aquele "não compartilha a semântica agentiva do v-zinho ativo, mas possui a propriedade da transitividade; junta-se a um argumento externo (benefactivo...) e checa o caso do objeto mais baixo". Sobre v-zinho causa como categoria funcional acima de v-zinho agentivo, ver Arad (1999, p. 17-19).

${ }^{45}$ Os dados da língua Ticuna se fazem presentes, nas seções seguintes deste artigo, por meio da representação escrita amplamente utilizada pelos falantes que vivem no Brasil. Sempre que pertinentes, observações sobre a fonologia serão introduzidas. Vale observar que dados de Soares (2009) constantes deste artigo confirmam aqueles de Soares (1987).

${ }^{46}$ Cf. Comrie (1976, 27f) e Cinque (1999, p. 90-91). Em termos interlinguísticos, o aspecto habitual é o mais "alto" de todos aspectos, o que faz com que tenda a ser indicado por meio de flexão ou através de morfemas gramaticais livres (como auxiliares). Há, no entanto, exceções, como é o caso do Aleúte, língua em que todos os aspectos 
são expressos derivacionalmente, incluindo-se o aspecto habitual (cf. CINQUE, 1999, p. 195, nota 50).

${ }^{47} \mathrm{O}$ sufixo em questão possui tom baixo.

${ }^{48}$ Os dados apresentados nesse ponto já haviam sido expostos em Soares (2000, p.101), publicação correspondente a Soares (1992b, volume I). Neles, as abreviaturas DAT (BEN) e NMLZR indicam, respectivamente, morfema dativo (benefactivo) e nominalizador. Para o uso de 'dativo(benefactivo)' como marca de caso no objeto, veja-se Soares (2000, 1992b).

${ }^{49}$ A operação de adjungir (ou adjunção) faz com que um termo, em uma configuração sintática, seja incorporado a uma estrutura sintagmática já existente: o adjunto está no mesmo nível de uma estrutura sintagmática e, ao mesmo tempo, é um subsegmento dessa última - o que é formalmente identificado através de um nódulo dobrado (no caso em questão o nódulo dobrado será $v$ ou $n$ ).

${ }^{50}$ Ver, a propósito, Chomsky (1995), que propôs eliminar o componente X-barra da gramática e reduziu toda construção de estrutura à operação Merge (Juntar), sendo que o conjunto de dois itens construídos por Merge tem o seu rótulo atribuído por cópia do rótulo de um deles (Bare Phrase Structure - 'Estrutura Frasal Despojada').

${ }^{51}$ A elaboração desse dicionário encontra-se em curso e, nele, vários falantes de Ticuna como primeira língua têm papel ativo, não se restringindo à posição de fornecedores de dados.

${ }^{52}$ Lembramos que o movimento mantém aqui um elo com o que será a linearização da sequência final.

${ }^{53}$ Rever, na seção 2.3, passagem sobre Arad (1999).

${ }^{54}$ Nos dados que se seguem, a estrutura acategorial é a que se encontra negritada.

${ }^{55}$ Presente em um dos dados a seguir, a abreviatura OI indica uma marca de 'objeto' interna ao verbo, que sempre vimos como um termo que participa da localização sintática de um sintagma situado fora do predicado, e não como um morfema estabelecedor de concordância. Em Soares (2000, p. 117-118), mostramos que a marca de 'objeto' interna ao verbo em Ticuna apresenta relacionamento patente com o clítico objetivo a partir de muitas generalizações descritivas. Sem serem consideradas como um dispositivo para o estabelecimento de concordância entre o verbo e o sintagma que, interpretado como objeto, constitui uma estrutura em adjunção, as marcas de 'objeto' internas ao verbo poderiam ser tratadas como resultado de um processo de incorporação dos clíticos, "abrindo-se, em função desse tratamento, espaço para um estudo sobre autorização de cadeias na língua”.Assim como os clíticos objetivos, a marca de 'objeto’ interna ao verbo é característica da aparente 
ordem superficial SVO em Ticuna. Os clíticos aparecem imediatamente à esquerda do verbo, recebem marca de caso e são sempre correferenciais a um sintagma em adjunção. Clíticos e marca interna de 'objeto' podem procurar livremente por seu antecedente (Ver SOARES, 2000, 1992b). Uma tal análise - voltada basicamente para a Teoria do Caso - em nada se assemelha àquela de Anderson (1966), que não busca saber qual é a relação entre o verbo e seus argumentos em Ticuna.

${ }^{56}$ Essa presença ou não da oclusão glotal na materialização do morfema causativo em Ticuna faz parte de um processo mais geral, presente na fonologia da língua e relacionável à variação linguística.

${ }^{57}$ Familiaridade, intimidade dizem respeito aqui ao sistema de parentesco Ticuna, isto é, o que é familiar ou íntimo define-se no interior desse sistema. Quanto à marca de terceira pessoa familiar e/ou de consideração em Ticuna, essa está relacionada à forma pronominal tüma 'ele/ela', que recupera necessariamente, no discurso, um antecedente explícito ou subentendido.

${ }^{58}$ A seguir, em determinados dados do Ticuna, ocorre um tipo de partícula integrante de um conjunto que se associa a um quadro maior de características. Trata-se do conjunto das partículas que, aparecendo na tradução justalinear como ' $x$ ', são indicadoras de estruturas em adjunção e são afetadas pelo Tempo (ver SOARES, 1992a, 1992b, 2000, 2005, 2007) e, ainda, a parte que escrevemos sobre a língua Ticuna e que consta de Maia et al. (1999). Assim: (a) i, ya/a 'não-passado'; (b) ga 'passado'. A relação dessas partículas com Tempo é muito clara no caso de $g a$, sempre ligado à idéia de passado. Quanto às outras partículas, seu significado básico, seria - por oposição a ga - a de não-passado. Essas partículas devem estar presentes no léxico, o que significa dizer que não podem ser um marcador "dummy" (ou, em uma visão não-lexicalista, que traços a elas relacionados devem ser parte da representação sintática de base). $\mathrm{O}$ falante nativo sabe que partícula pode preceder determinado item lexical na configuração sintática apontada. Com relação ao formato da construção Ticuna correspondente ao que em português é uma oração relativa e também presente em dados a seguir, remetemos o leitor a Soares (2000, p. 146-149), onde é possível ler que: “A estrutura interna das orações relativas em Ticuna não nos permite... falar em extração de frase nominal. A isso se adiciona o fato de as 'orações relativas' serem construções nominais... caracterizadas pela presença de uma partícula (ya) e de um morfema nominalizador (-cü)."

${ }^{59}$ Nos dados em (17b) e (17c), é possível observar a presença do sufixo gü 'reflexivo/ recíproco’ que, aparecendo em forma pronominal, é portador de tom baixo. Esse contrapõe-se ao sufixo gü que, fonologicamente caracterizado por tom alto, ocorre tanto em nomes quanto em verbos e é uma das formas que, na língua, expressam 
plural/quantidade de elementos vistos em grupo.Quanto ao dado em (17d), esse apresenta, como item lexical correspondente ao termo mãe, uma forma emprestada, a nosso ver, de longa data. Embora essa última seja de uso corrente entre os falantes Ticuna que estão no Brasil, é possível encontrar vários que ainda utilizam a palavra tradicional o'ẽ para 'mãe'. E, a propósito da forma pronominal tüma 'ele/ela', que aparece nos dados (17 d, e), reveja-se a nota 57.

${ }^{60}$ Como os dados apresentados integram pesquisa desenvolvida com vários consultores nativos pertencentes a diferentes locais da área Ticuna (que é extensa), indicamos não só o ano de obtenção /publicação do dado, mas também a inicial do nome em português do consultor que o forneceu.

${ }^{61} \mathrm{Em}$ (18a), ocorre a palavra Tunetü, nome de um igarapé relacionado à origem mítica do povo Ticuna.

${ }^{62}$ Utilizamos algumas evidências gramaticais para a distinção entre inacusativos e inergativos em Ticuna. Essa língua não apresenta verbos auxiliares - o que permitiria (como se fez, por exemplo, para o italiano e o holandês) uma investigação detalhada sobre verbos intransitivos e sua divisão interna, por meio da seleção de verbo auxiliar. Na ausência da possibilidade desse meio de investigação para o Ticuna, lançamos mão dos seguintes critérios:a existência e a análise de construções resultativas; a existência e a análise de duas classes de verbos consideradas como inacusativas, mas que não podem aparecer com sintagmas resultativos: a) a dos verbos estativos; b) a dos verbos de movimento inerente, como 'vir', 'ir', 'chegar'. O Ticuna possui verbos de movimento inerente, sendo que esse movimento recebe, na maioria dos casos, codificação morfológica - uma codificação que também se verifica em alguns exemplos de mudança de estado. Por fim, em se tratando da causativização, verbos que, em Ticuna, podem ser considerados como inacusativos têm o seu tema relacionado a uma marca interna ao próprio verbo ou a um clítico- o que pode ser tomado como evidência de que seu aparente ‘sujeito' origina-se de um DP tema.

${ }^{63}$ Rever a propósito a apresentação dos dados em (16), assim como aqueles em (17).

${ }^{64}$ Com essa característica, a segunda oração mostra-se como um grande nome relacionável à primeira.

${ }^{65}$ Ver nota 55.

${ }^{66}$ Rever nota 28.

${ }^{67}$ Embora tais advérbios não estejam entre aqueles habitualmente usados por semanticistas para testar estrutura de eventos complexa, acreditamos que são promissoras as perspectivas de aprofundamento da análise que, a esse respeito, é aqui iniciada. 


\section{Referências bibliográficas}

ANDERSON, L. The structure and distribution of Ticuna independente clauses. Linguistics, vol.20. Paris, Mouton \& Co., 1966.

ARAD, M. On "little v". MIT Working Papers in Linguistics. Cambridge, n.33, p. 1-25, 1999.

CHOMSKY, N. Minimalist inquiries: the framework. MIT Occasional Papers in Linguistics, MIT, 1998.

CHOMSKY N. The minimalist program. Cambridge, M.A.: MIT Press, 1995.

CINQUE, G. Adverbs and functional heads. A cross-linguistic perspective. New York, Oxford: Oxford University Press, 1999.

COMRIE, B. Aspect. Cambridge: Cambridge University Press, 1976.

CULICOVER, P. W.; JACKENDOFF, R. Simpler syntax. Oxford: Oxford University Press, 2005.

HALE, K.; KEYSER, S. J. On argument structure and the lexical expression of syntactic relations. In: HALE, K.; KEYSER, S. J. (Ed.). The view from Building 20: Essays in honor of Sylvain Bromberger. Cambridge: MIT Press, 1993.

HARLEY, H. On the causative construction [2006]. In: MIYAGAWA, S.; SAITO, M. The handbook of Japanese Linguistics. Oxford: Oxford University Press, 2008.

HARLEY, H. Possession and the double object construction. Linguistic Variation Yearbook 2: p. 31-70, 2002.

HARLEY, H. Subjects, events and licensing. PhD. Dissertation, MIT, 1995.

HORNSTEIN, N.; NUNES, J.; GROHMANN, K. K. Understanding minimalism. Cambridge: Cambridge University Press, 2005.

JACKENDOFF, R. On Larson's treatment of the double object construction. Linguistic Inquiry 21 (3): p. 427-456, 1990.

KRATZER, A. Severing the External Argument from its Verb. In: ROORYCK, J.; ZARING, L. (Ed.). Phrase Structure and the Lexicon. Dordrecht: Kluwer Academic Publishers, 1996.

KOOPMAN, H.; SPORTISCHE, D. The position of subjects. Lingua 85, p. 211-58, 1991.

LARSON, R. On the double object construction. Linguistic Inquiry 19, p. 335-391, 1988.

LARSON, R. Double objects revisited: reply to Jackendoff . Linguistic Inquiry 21, p. 589-632, 1990.

MAIA, M. et al. A estrutura da oração em línguas indígenas brasileiras. DELTA, v.15 n.1, São Paulo, fev./jul.1999. 
MARANTZ, A. No escape from syntax: don't try morphological analysis in the privacy of your own lexicon. In: DIMITRIADIS, A; SIEGEL, L; SUREK-CLARK, C.; WILLIAMS, A. (Ed.). Proceedings of the $21^{\text {st }}$ Penn Linguistics Colloquium. Upenn Working Papers in Linguistics. Philadelphia, 1997. p. 201-225.

MARANTZ, A. On the nature of grammatical relations. Cambridge: MIT Press, 1984.

PYLKKÄNEN, L. Introducing arguments. PhD dissertation, MIT, 2002.

RADFORD, A. Syntax. A minimalist introduction. Cambridge: Cambridge University Press, 1997.

SOARES, M. F. Dados da língua Ticuna. Curso na aldeia Filadélfia, julho/agosto de 2009. Ms. Museu Nacional/UFRJ, 2009.

SOARES, M. F. Língua/Linguagem e tradução cultural: algumas considerações a partir do universo Ticuna. Boletim do Museu Paraense Emílio Goeldi. Ciências Humanas, Belém, v. 3 n. 1, 2008.

SOARES, M. F. Aspects de la modalité épistémique en ticuna. In: GUENTCHÉVA, Zlatka; LANDABURU, Jon (Ed.). L'énonciation médiatisée II. Le traitement épistémologique de l'information: illustrations amérindiennes et caucasiennes. Louvain - Paris: Éditions Peeters, 2007. p. 219-240.

SOARES, M. F. Da representação do Tempo em Tikuna. In: RODRIGUES, A. D.; CABRAL, A.S. (Org.). Novos Estudos sobre Línguas Indígenas. Brasília, Universidade de Brasília, 2005. p. 153-167.

SOARES, M. F. Variação e análise paramétrica: algumas possibilidades de estudos em línguas indígenas brasileiras. Gragoatá, Niterói, n.9, p. 45-65, 2001.

SOARES, M. F. O supra-segmental em Tikuna e a teoria fonológica. Volume I. Investigação de aspectos da sintaxe Tikuna. Campinas: Editora da UNICAMP, 2000.

SOARES, M. F. Ordem de palavra: primeiro passos para uma relação entre som, forma e estrutura em tikuna. Amerindia, Paris, n.17, 1992a.

SOARES, M. F. O supra-segmental em Tikuna e a teoria fonológica. Volume I. Investigação de aspectos da sintaxe Tikuna. Volume II: Ritmo. Tese de Doutorado. Campinas, IEL/UNICAMP, 1992b.

SOARES, M. F. Dados da língua Ticuna. Aldeia Canimaru. Ms. Museu Nacional/ UFRJ, Setor de Linguística, 1987.

SOARES, M. F. Tchorü du'ü)ü)güca' tchanu (Minha luta pelo meu povo). Relato da vida de Pedro Inácio Pinheiro (Ngematücü). Ms. Museu Nacional/UFRJ, Setor de Linguística, 1984. 